\title{
Biogeographic patterns on Kimberley islands, Western Australia
}

\author{
L.A. Gibson \\ Department of Parks and Wildlife, Science and Conservation Division, PO Box 51, Wanneroo, \\ Western Australia 6946, Australia. \\ Email: Lesley.Gibson@dpaw.wa.gov.au
}

\begin{abstract}
Australia's islands play a significant role in the conservation of its biota. The near-pristine islands along the Kimberley coast of north-western Australia are important natural refuges that have been relatively isolated from many of the threatening processes affecting the adjacent mainland. Between 2007 and 2010, 24 of the largest of these islands were surveyed for non-volant mammals, reptiles, birds, frogs, bats, land snails and vascular plants. To facilitate the setting of conservation priorities, I examined congruence in the biogeographic patterns among these taxonomic groups and related those to island-wide attributes. A high level of congruence in both spatial patterns of species richness and community similarity across most of the taxonomic groups was found. Congruence in species richness was best explained by a strong relationship with island area; while congruence in community similarity was influenced by the dispersal ability of taxa. Average annual rainfall and the extent of rock scree (or ruggedness) on an island were also strong correlates of both spatial patterns in community similarity and richness of regional endemics. I also show that this pattern was not explained by richness differences of species between islands alone, but largely due to species replacement among islands. These patterns reflect the greater diversity of regional endemic species and/or habitat specialists that are restricted to the relatively high rainfall and extensively rocky islands; whereas the drier islands typically support widespread generalists that have distributions that extend into the semi-arid and arid zones. In terms of conservation significance, the largest islands in the most mesic section of the coast are important for their high species diversity, including regional endemics. However, the lower rainfall islands support unique assemblages, and some are also important for their threatened mammal species. The high level of island endemism of the camaenid land snails indicates that all the islands sampled are important in terms of representing their diversity. The results of the survey also support the hypothesis that these islands are microcosms of the adjacent Northern Kimberley mainland with $74 \%$ of mammal, $59 \%$ of reptile, $70 \%$ of frog, $69 \%$ of bird and $49 \%$ of plant species of the Northern Kimberley bioregion now known on the islands sampled. Future management of the islands requires strategies that minimise the risk of incursions by exotic species and appropriate fire regimes to preserve habitat quality.
\end{abstract}

KEYWORDS: biodiversity patterns, community similarity, congruence, island biogeography, island conservation, species richness, species turnover

\section{INTRODUCTION}

Australia's islands have long been recognised for their conservation value, particularly as refuges for native mammals that have suffered extensive contractions of their mainland distributions (Burbidge 1999; Burbidge et al. 1997; Woinarski et al. 2001, 2011a). These islands are also important for the many endemic and threatened species they support and many provide vital breeding sites for numerous seabirds and sea turtles (Ecosure 2009; CCWA 2010; Nias et al. 2010). While islands may act as biodiversity refugia, they are also susceptible to dramatic ecosystem changes should they be exposed to environmental disturbances such as grazing by cattle or feral herbivores, fire and invasion by exotic species (Burbidge and Manley 2002; Laurance et al. 2011; Walshe et al. 2011). Globally, extinction rates are exponentially greater on islands with well over half of bird, mammal, reptile and plant extinctions being island species (Island Conservation 2007). This highlights the importance of protecting islands from deleterious disturbances and the need to develop stringent biosecurity plans (Nias et al. 2010).

Just under a third of Australia's islands occur off the Kimberley coast of north-western Australia (CCWA 2010). The more than 2500 islands along this coast were formed as a result of rising sea levels that occurred up to 10,000 years ago (Nix and Kalma 1972; Burbidge and McKenzie 1978). 
Of these, only 145 islands are at least 100 ha in area and just 20 are greater than 1000 ha (CCWA 2010). The Kimberley islands have been relatively isolated from many of the threatening processes affecting the adjacent mainland (McKenzie et al. 2009). With a few exceptions, the islands have remained largely free of invasive species. Pastoral activity has also been extremely limited on the islands and they are less altered by fire compared to the adjacent mainland (McKenzie et al. 2009). The high conservation value of these near-pristine islands, but lack of knowledge of the biodiversity on a large majority of them, led to the instigation of a biological survey of a select number of the largest islands along the north Kimberley coast, commencing in 2007 - the Kimberley Island Biodiversity Survey (KIBS; see Gibson and McKenzie 2012a). The primarily aim of the KIBS was to determine the biodiversity values of these islands, and thereby provide the baseline knowledge necessary for underpinning decisions on conservation, recreation and sustainable development.

The KIBS focused on species thought to be most at risk from threatening processes affecting biodiversity on the Kimberley mainland. The taxonomic groups targeted include the nonvolant mammals, bats, reptiles, frogs, land snails and vascular plants, and birds were sampled opportunistically (see Gibson and McKenzie 2012a). Assessments of the biogeographic patterns in relation to island-wide attributes for each of these groups have been presented in a series of papers (see Doughty et al. 2012; Gibson and Köhler 2012; Gibson and McKenzie 2012b; McKenzie and Bullen 2012; Pearson et al. 2013; Palmer et al. 2013; Lyons et al. 2013). Overall, the survey revealed the presence of additional island populations of many vertebrates, and more than doubled the species lists for most of the islands where prior biological information existed. This includes newly discovered populations of threatened mammals on islands, plus at least three reptile species, and 73 camaenid land snail species yet to be discovered on the adjacent mainland.

Here, to facilitate the setting of conservation priorities, I aggregated the biological data obtained during the KIBS to identify common biogeographic patterns among the taxonomic groups. Common patterns (or congruence) between multiple taxonomic groups helps to prioritise areas for conservation effort, as conservation actions for one group are also likely to benefit the others (Howard et al. 1998; Moritz et al. 2001; Pawar et al. 2007; Heino 2010). Specifically, I evaluate cross-taxon congruence in both species richness (i.e. alpha diversity) and assemblage composition (often referred to as community similarity/ dissimilarity or beta diversity) of the targeted groups across the islands sampled. I then examine what biogeographical and environmental factors (e.g. island area and isolation, topography and climate) correlate with the observed patterns of congruence in both species richness and assemblage composition. Finally, I analyse the relationship between richness of endemic species and biogeographical and environmental factors. The conservation implications of the results are discussed in detail.

\section{METHODS}

\section{THE ISLANDS}

We selected a subset of the largest islands for sampling, targeting those with a variety of geological surfaces, as well as ensuring geographic coverage from north to south (see Gibson and McKenzie 2012a). Although many islands along this coastline are separated from the mainland by only narrow channels, we avoided those connected to the mainland by mangroves, littoral mudflats or reef exposed at low tide. We also excluded islands with existing mining operations and those under exploration for natural resource extraction. The 24 islands selected extend from Sir Graham Moore Island off the Anjo Peninsula in the north to Sunday Island near Cape Leveque in the south, and to Adolphus Island in the Cambridge Gulf in the east (Figure 1). With the exception of Sunday Island, all of the islands sampled fall within the Northern Kimberley IBRA biogeographic region (Thackway and Cresswell 1995). Although Sunday Island falls within the adjacent Dampierland IBRA biogeographic region, it has closer geological affinities with the Northern Kimberley.

All 24 islands are currently uninhabited, although an outstation on Sunday Island and a fishing camp on Lachlan Island are used for short visits. History of pastoral activity on the islands is negligible. Animals were introduced on Sunday Island (goats, cattle and pigs) and Sir Graham Moore Island (goats and pigs), but only a low density of feral pigs remain on Sir Graham Moore (at the time of the KIBS).

The geomorphology of the islands resembles that of the adjacent mainland, although even the largest islands generally include only two or three of the Precambrian rock types present on the mainland (see Burbidge and McKenzie 1978; Burbidge et al. 1991). General geological and vegetation descriptions of the islands are given in Gibson and McKenzie (2012a), with more detail on the vegetation presented in Lyons et al. (2013). Briefly, sandstone and volcanic strata structure the island landscapes. The sandstone units tend 


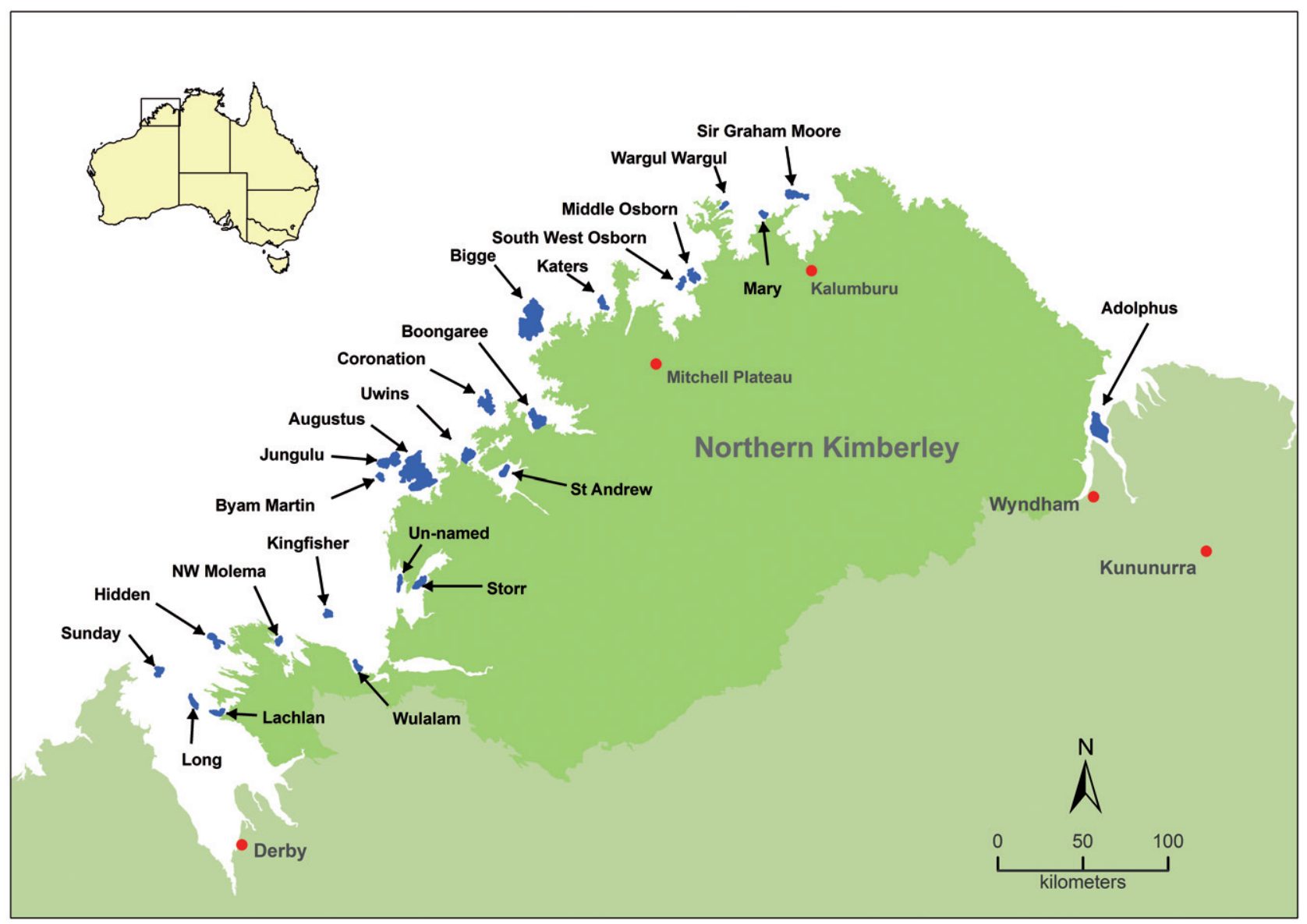

FIGURE 1 Location of Kimberley islands selected for a survey of their biodiversity assets along the north-west coast of Australia.

to give rise to rugged, dissected terrains, while the volcanics usually produce a more rounded and undulating topography. Tertiary duricrusts occur as mesas and dissected tablelands on some islands, capping volcanic or sandstone strata. Broad vegetation communities on the islands include tropical savannas, hummock grassland, monsoonal rainforest (including coastal vine-thickets), coastal tussock grassland, riparian paperbark woodlands and mangroves.

The Kimberley experiences a tropical monsoon climate with a pronounced dry season extending from around April to October, and a wet season from November to March when almost all rainfall occurs. Cyclonic activity is also a feature of the climate, with an average of two cyclones crossing the northwest Australian coast each cyclone season (http://www.bom.gov.au/cyclone/climatology/ wa.shtml). Average annual rainfall ranges from $1500 \mathrm{~mm}$ in the northwest to $800 \mathrm{~mm}$ in the southeast, and average temperatures range from a daily maximum of $33^{\circ} \mathrm{C}$ in January to a night time minimum of $15^{\circ} \mathrm{C}$ in July (http://www.bom.gov.au).

\section{SAMPLING DESIGN}

A description of the KIBS design and implementation is given in Gibson and McKenzie (2012a). Briefly, campsites on the islands were selected using information on geology and vegetation from maps, local knowledge, satellite imagery, and a reconnaissance flight. For easy access, campsites needed to be placed within walking distance of as many habitat types as possible. Two campsites were needed to access the environmental variation of the largest islands. Wanjina-Wunggurr Uunguu, Wanjina-Wunggurr Dambimangari and Bardi-Jawi native title determinations, and Balanggarra and Mayala native title claims together cover all the islands surveyed (see Vigilante et al. 2013). Accordingly, all sites were presented to the Traditional Owners for their approval. In the dry season, campsites were accessed by helicopter and sampled over a six-day period. Sites were then revisited in the wet season using a combination of charter boat and helicopter, and sampled over a single day and night. In total, 31 campsites were sampled over four dry and three wet seasons from 2007 to 2010. 


\section{SPECIES DATA}

The sampling strategy used was specific to each of the targeted taxonomic groups and detailed elsewhere (see Doughty et al. 2012; Gibson and Köhler 2012; Gibson and McKenzie 2012b; McKenzie and Bullen 2012; Pearson et al. 2013; Palmer et al. 2013; Lyons et al. 2013). We aimed to sample each of the taxonomic groups as systematically as possible within each of the selected habitat types. However, birds were sampled opportunistically due to time constraints (i.e. from sightings and calls) and search emphasis was placed on specific habitats for groups such as the frogs and bats (e.g. wetlands), and land snails (e.g. rainforest vegetation). Data for each of the taxonomic groups were pooled across habitat type and survey occasion. To increase the comprehensiveness of these lists, the data were supplemented with verified records from previous surveys (with the exception of the plants - due to overwhelming sampling bias) and constituted a 'best-available' species list for each of the islands sampled. Species restricted to mangroves were also removed from the analyses as this habitat type was not adequately or evenly sampled among islands. Access to mangroves was often limited as some sites were located inland. Non-native animal species were excluded from the analyses as there were so few detected (feral pigs were detected on a single island), however introduced weeds were retained.

I excluded frogs from the quantitative analyses as an unusually dry 'wet' season during the final year of sampling was likely to have reduced the chance of detecting frogs on the islands surveyed. Indeed, no frogs were detected on seven out of the nine islands sampled that season (see Table 1). Additionally, I divided the land snails into two groups for the analyses - camaenids and noncamaenids - due to their vastly different dispersal capacities (see Gibson and Köhler 2012).

\section{ISLAND ATTRIBUTES}

I selected a common set of attributes that have been shown to influence species richness and assemblage composition on islands (e.g. Ricklefs and Lovette 1999; Burbidge et al. 1997; Woinarski et al. 1999; Dennis et al. 2012; Yu et al. 2012). These include island area, distance to the mainland, average annual rainfall, maximum elevation of an island, proximity to river mouth and maximum temperature of the warmest period of the year. I also included two (ordinal) habitat descriptors: 'boulder' which represents the extent of rock scree on each island ( $0=$ flat; $1=$ rounded, soilmantled hill slopes and plateaux, narrow scree; 2 = shallow joints, wide ledges, moderate scree; 3 = massive scree, deep joints and scarp country) and 'rainforest' representing the extent of monsoon rainforest on each island (0-3; none to substantial large patches on islands). Island size was defined as the area of land mass (ha) that was unlikely to be inundated (i.e. tidal mudflats and mangroves were excluded), and was determined from digitised 1:100,000 topographic maps. Maximum elevation (m) was extracted from the 1:100,000 topographic maps. Distance to the mainland $(\mathrm{km})$ was estimated using Google Earth ${ }^{\mathrm{TM}}$ imagery. Climate attributes were derived using the BIOCLIM module of ANUCLIM (Houlder et al. 2000). Using ArcMap GIS (ESRI Inc., Redlands, California, USA), values of the climate attributes were extracted for each site sampled on an island as well as either four (one-site islands) or six (two-site islands) additional random sites across the islands and averaged for each island. Pairwise Pearson correlations among all candidate variables revealed a strong intercorrelation between rainforest and rainfall $(P=0.8)$; the latter was retained in the analysis as rainforest was largely subjective and rainfall was considered more informative. Both island area and distance to the mainland was log-transformed prior to analysis. Values for each of the attributes are given in Appendix 1.

\section{CROSS-TAXON CONGRUENCE}

\section{SPECIES RICHNESS}

Correlations in island species richness between taxonomic groups were examined using the Spearman's rank correlation test. To examine what island attributes correlate with the observed patterns of congruence, all possible subsets of the island attributes were modelled against species richness using generalised linear modelling (GLM), assuming a Poisson distribution. Models were ranked according to the second-order Akaike Information Criterion (AIC) and $\mathrm{AIC}_{c}$ weights (or model probabilities) were calculated (Burnham and Anderson 2002). I included all models in the final candidate set for model averaging to estimate parameters. The relative importance of each of the island attributes in defining species richness was examined by summing the $\mathrm{AIC}_{c}$ weights for each attribute across all models in which it occurred $\left(w_{+}\right.$; Burnham and Anderson 2002). Data analyses were run in the $\mathrm{R}$ statistical computing language ( $R$ Development Core Team 2009).

\section{ASSEMBLAGE COMPOSITION}

Correlations in community similarity between taxonomic groups were examined using the Mantel test. For all groups, species similarity between all pairs of islands (based on presence/absence data) was computed using the Sørensen association 


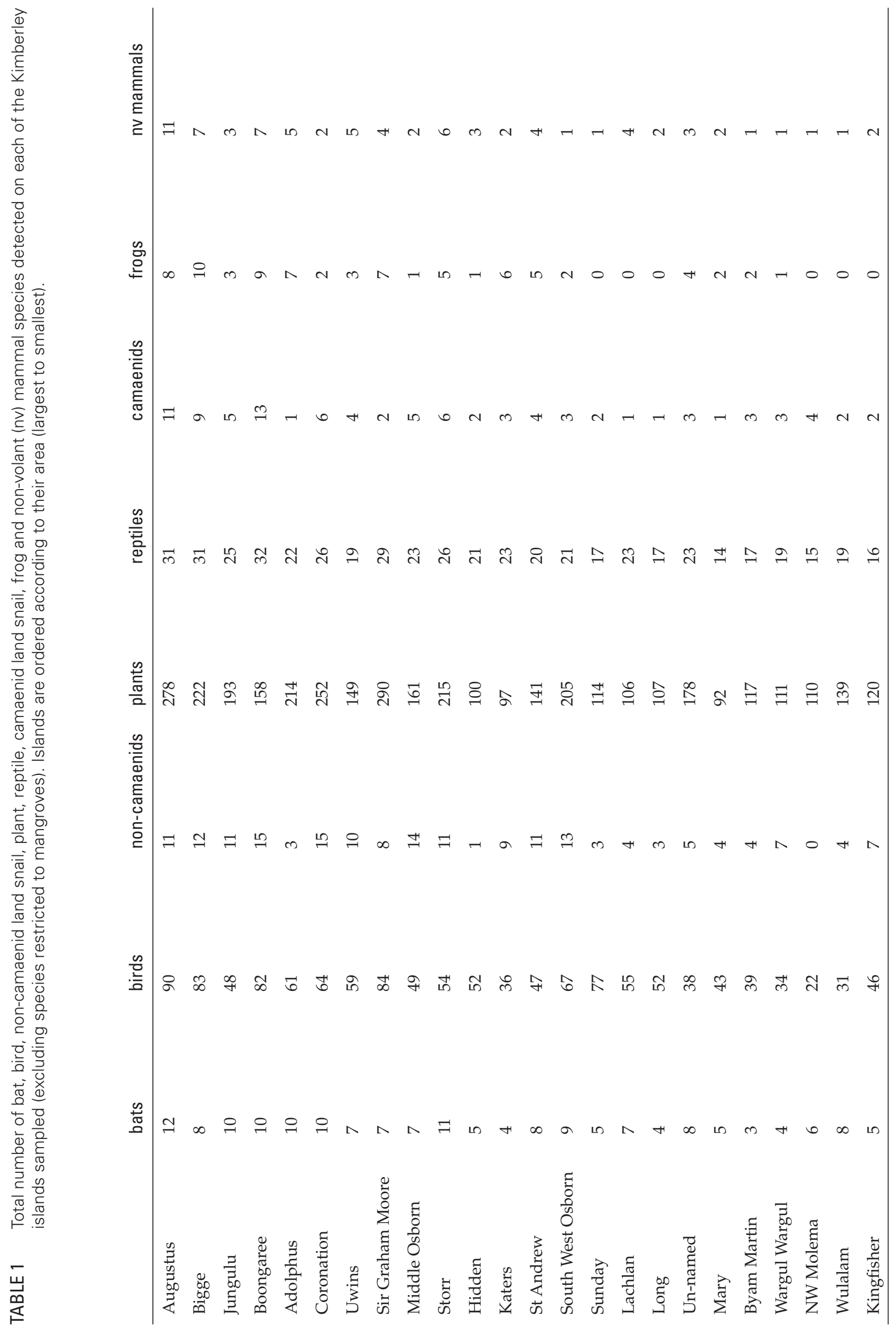


TABLE 2 Correlations between bats, birds, camaenid land snails, non-camaenid land snails, non-volant (nv) mammals, vascular plants and reptiles across the 24 Kimberley islands for community similarity (below diagonal) and species richness ${ }^{b}$ (above diagonal).

\begin{tabular}{llllllll} 
& bats & birds & camaenids & non-camaenids & nv mammals & plants & reptiles \\
\hline bats & - & $0.49^{*}$ & $0.54^{* *}$ & $0.56^{* *}$ & $0.59^{* *}$ & $0.78^{* * *}$ & $0.68^{* * *}$ \\
birds & $0.26^{*}$ & - & 0.25 & $0.41^{*}$ & $0.59^{* *}$ & $0.61^{* *}$ & $0.60^{* *}$ \\
camaenids & -0.10 & -0.02 & - & $0.76^{* * *}$ & 0.37 & $0.54^{* *}$ & $0.59^{* *}$ \\
non-camaenids & $0.26^{*}$ & $0.60^{* *}$ & 0.003 & - & 0.37 & $0.61^{* *}$ & $0.67^{* * *}$ \\
nv mammals & 0.06 & 0.03 & 0.09 & 0.07 & - & $0.48^{*}$ & $0.69^{* * *}$ \\
plants & $0.35^{* *}$ & $0.44^{* *}$ & 0.02 & $0.37^{* *}$ & 0.16 & - & $0.69^{* * *}$ \\
reptiles & $0.39^{* *}$ & $0.56^{* *}$ & 0.04 & $0.47^{* *}$ & 0.05 & $0.64^{* *}$ & - \\
\hline
\end{tabular}

a Mantel's r; ${ }^{b}$ Spearman's r; ${ }^{*} P<0.05 ; * * P<0.01 ; * * * 0.001$

measure. Mantel tests were then used to examine the relationship between each pair of similarity matrices. The significance of the relationships between the matrices was examined using a Monte-Carlo procedure with 999 permutations. The resulting matrix of Mantel correlation coefficients was imported into the package PRIMER v6 (Clarke and Gorley 2006), rescaled using non-metric multidimensional scaling (nMDS) in two dimensions (minimum stress of 0.005 and 100 restarts) and displayed as a scatter plot.

Following Baselga (2010), I also calculated multiple-site (i.e. island) dissimilarities to give an overall measure of beta diversity (based on the Sørenson index - beta.SOR) for each taxonomic group, and partitioned the beta diversity into two additive components: one accounting for spatial turnover (i.e. multiple-site Simpson index - beta. SIM) and the other accounting for the contribution of richness differences to overall beta diversity (multiple-site 'nestedness' index - beta.NES). Tests of congruence and calculations of beta diversity were performed within the $\mathrm{R}$ statistical computing package (R Development Core Team 2009) using source code from Baselga (2010).

Congruent groups (i.e. Spearman correlations $<0.05$ ) were pooled to further examine compositional patterns in the multi-taxon community across the islands sampled. Discordant groups were treated separately. Again using PRIMER, compositional similarity between all pairs of sites (based on presence/absence data) was computed using the Sørensen association measure and the dimensionality of the similarity matrix was reduced using nMDS. The resultant association matrix was clustered using the unweighted pair group method with arithmetic mean (UPGMA).

To explore the relationship between compositional similarity and island attributes, I used the BEST/BIOENV procedure in PRIMER where the distances in the similarity matrix are rank-order matched with the Euclidean distances among each of the island attributes (see below) using Spearman's rank correlation. This procedure calculates the Spearman's rank correlation coefficient (rho) using every possible combination of the predictor variables until it finds the combination whose Euclidian distance matrix yields the highest value of rho (Geffen et al. 2004). Pairwise Pearson correlations between all candidate attributes revealed no strong intercorrelations (i.e. $P<0.8$ ).

The degree of spatial structure (or distance decay) in species composition was examined using Mantel tests. A Euclidian distance matrix was calculated for geographical distance based on the geographical coordinates of the mid-points of the islands. Partial Mantel tests were then used to examine the relationship between species similarity and each of the environmental attributes (after calculating Euclidian distance matrices for each attribute), while holding the geographic distance matrix constant. The significance of the relationships between the matrices was examined using a MonteCarlo procedure with 999 permutations. Partial Mantel tests were performed within the R statistical computing package ( $\mathrm{R}$ Development Core Team 2009).

\section{RICHNESS OF ENDEMIC SPECIES}

The number of species detected on each island that are endemic to the Northern Kimberley, or near-endemic to it (i.e. with distributions centred on the Northern Kimberley), was tallied for each of the taxonomic groups. The association between total number of endemic species and all possible subsets of the island attributes was modelled by using a generalised linear model (GLM), assuming 
a Poisson distribution. Model selection was based on the second-order Akaike Information Criterion (AIC) (Burnham and Anderson 2002). I included all models in the final candidate set for model averaging to estimate parameters. I also calculated AIC $c$ weights $\left(w_{i}\right)$ and used these to weight model coefficients. The relative importance of island attributes was examined by summing the $\mathrm{AIC}_{c}$ weights for each covariate across all models in which it occurred $\left(w_{+}\right.$; Burnham and Anderson 2002). Data analyses were run in the $R$ statistical computing language ( $\mathrm{R}$ Development Core Team 2009). I evaluated the performance of the averaged model by regressing the fitted values against observed species richness values.

\section{RESULTS}

\section{CONGRUENCE AND SPATIAL PATTERNS IN SPECIES RICHNESS}

Species richness varied considerably across taxonomic groups and islands (Table 1). However, there was a high degree of congruence in the spatial pattern of species richness between the groups with many significant positive correlations observed (Table 2). The exceptions were the relationship between species richness of the camaenid land snails and both the birds and non-volant mammals, and between the non-camaenid land snails and the non-volant mammals (Table 2).

The relative importance of each island attribute based on the sum of the Akaike weights of the models that include the attribute reflect the relationships above (Table 3). Of the attributes considered, island area was the most important attribute defining species richness for all the groups, except land snails where rainfall was the most important. Model coefficients indicating the sign of the relationships are presented in Appendix 2. Additionally, correlating the number of frogs detected on the 16 islands considered to be sufficiently sampled for frogs (see Doughty et al. 2012) with the island attributes using the Spearman rank test showed that only island area was significantly correlated with richness (rho = $0.51, P<0.05)$.

\section{CONGRUENCE AND SPATIAL PATTERNS IN COMMUNITY SIMILARITY}

Community similarity matrices of the birds, plants, reptiles, bats and non-camaenid land snails were all significantly intercorrelated $(P<0.05)$ (Table $2)$. Among this group, lowest correlations were evident between the bats and all the other groups (Table 2, Figure 2A). Both the non-volant mammals and camaenid land snails show poor congruence with each other and any of the other groups (Table 2, Figure 2B).

Multiple-site (island in this case) beta diversity (beta.SOR) and its additive components (beta. SIM and beta.NES) were largely similar among the taxonomic groups (Table 4). In almost all cases spatial turnover (beta.SIM) was responsible for most of the beta diversity. The one exception was for the non-camaenid land snails whereby both spatial turnover and 'nestedness', i.e. 'thinning' of the species on each island from that of the richest island sensu Sfenthourakis and Panista (2012), contributed similarly to beta diversity.

TABLE 3 The relative importance of island attributes, in terms of influencing species richness of bats, birds, camaenid land snails, non-camaenid land snails, non-volant (nv) mammals, plants and reptiles, based on the sum of the Akaike weights of the models that include the attribute. The higher the value, the higher the relative importance.

Key: area - area of island, boulder - extent of rock scree, distance - distance to the mainland, elevation - maximum elevation, rain - average annual rainfall, river - proximity to river mouth.

\begin{tabular}{lcccccc} 
& area & boulder & distance & elevation & rain & river \\
\hline bats & 0.70 & 0.21 & 0.23 & 0.46 & 0.27 & 0.29 \\
birds & 1.00 & 0.27 & 0.20 & 0.28 & 0.64 & 0.24 \\
camaenids & 0.52 & 0.37 & 0.33 & 0.39 & 0.94 & 0.21 \\
non-camaenids & 0.19 & 0.19 & 0.19 & 0.25 & 1.00 & 0.20 \\
nv mammals & 1.00 & 0.18 & 0.56 & 0.20 & 0.19 & 0.52 \\
plants & 1.00 & 1.00 & 0.78 & 0.27 & 0.99 & 0.41 \\
reptiles & 0.99 & 0.20 & 0.30 & 0.19 & 0.21 & 0.20 \\
\hline
\end{tabular}




\section{CONGRUENT GROUPS COMBINED}

Based on the above result, birds, bats, reptiles, non-camaenid land snails and plants were pooled for further examination of spatial patterns in composition of this congruent group. The BIOENV procedure indicated that of the seven island attributes considered, a combination of average annual rainfall, the extent of rock scree on an island (or boulder) and maximum temperature of the warmest period had the strongest association with compositional similarity (Spearman's rho $=0.57$ ). Geographical distance confounded the relationship between these attributes and compositional similarity to some degree, as compositional similarity also decreased with geographical distance (Mantel $\mathrm{r}=-0.56, P<0.01$ ). However, when I corrected for the effect of geographical distance, the correlation of compositional similarity with both boulder and rainfall (expressed as Euclidian distances) remained significant (Mantel $\mathrm{r}=-0.37$, $P<0.01$, Mantel $\mathrm{r}=-0.16, P<0.05$, respectively), but maximum temperature did not (Mantel $\mathrm{r}=-0.10, P$ $=0.20$ ).

These associations are overt in the main clusters of the nMDS ordination. Using groups defined at the $40 \%$ similarity level, three main clusters containing most of the islands are apparent (Figure 3). An additional four islands are represented by lone groups (Figure 3). The 12 islands in the largest cluster are geographically located in the most north-westerly section of the Northern Kimberley coastline (Figure 1), an area that receives relatively high annual rainfall (>1000 mm). Rugged, deeply dissected boulder country with sheer scarps and the presence of monsoonal rainforest patches are major features of most of these island's landscapes. Sir Graham Moore Island is the exception among this cluster (a lower rainfall island in the northern most section of the study area), and is probably grouped here because of its high species richness, as the islands within this cluster are the most species-rich (Table 1). A further island in the high rainfall zone, Katers Island, had unusually low species diversity, and this is reflected in the ordination, forming a single-island cluster (Figure 3).

A further cluster of four islands (Hidden, Long, Lachlan and Sunday) all occur in the drier southern section of the Northern Kimberley coast (Figure 1). These four sandstone islands receive an average annual rainfall of less than $850 \mathrm{~mm}$, and consequently they do not have well-developed rainforest patches. They are also less species-rich than the cluster above (Table 1).

Wulalam, NW Molema, Kingfisher and Byam Martin Islands form a third cluster. With the exception of Byam Martin, these islands are relatively closely located in Collier and Talbot Bays and receive a similar annual rainfall $(\sim 900 \mathrm{~mm})$. The islands in this cluster are among the smallest sampled and this is reflected by their comparatively low species numbers (Table 1), and probably explains why Byam Martin, a 'high' rainfall but a small island, is grouped here. These islands are generally less rugged than those in the clusters above, and they do not have well-developed and extensive rainforest patches.

TABLE 4 Additive partitioning of beta diversity following Baselga (2010) for bats, birds, camaenid land snails, noncamaenid land snails, non-volant (nv) mammals, plants and reptiles between all pairs of the sampled Kimberley islands. The beta.SOR is the multiple-site pairwise Sorensen dissimilarity, partitioned into a replacement component (beta.SIM) and a component accounting for the contribution of richness differences to overall beta diversity (beta.NES).

\begin{tabular}{lrrr} 
& beta.SOR & beta.SIM & beta.NES \\
\hline bats & 0.84 & 0.73 & 0.11 \\
birds & 0.85 & 0.77 & 0.08 \\
camaenids & 0.99 & 0.99 & 0.00 \\
non-camaenids & 0.85 & 0.56 & 0.29 \\
nv mammals & 0.92 & 0.84 & 0.08 \\
plants & 0.91 & 0.88 & 0.03 \\
reptiles & 0.87 & 0.82 & 0.04 \\
congruent & 0.90 & 0.86 & 0.04 \\
\hline
\end{tabular}




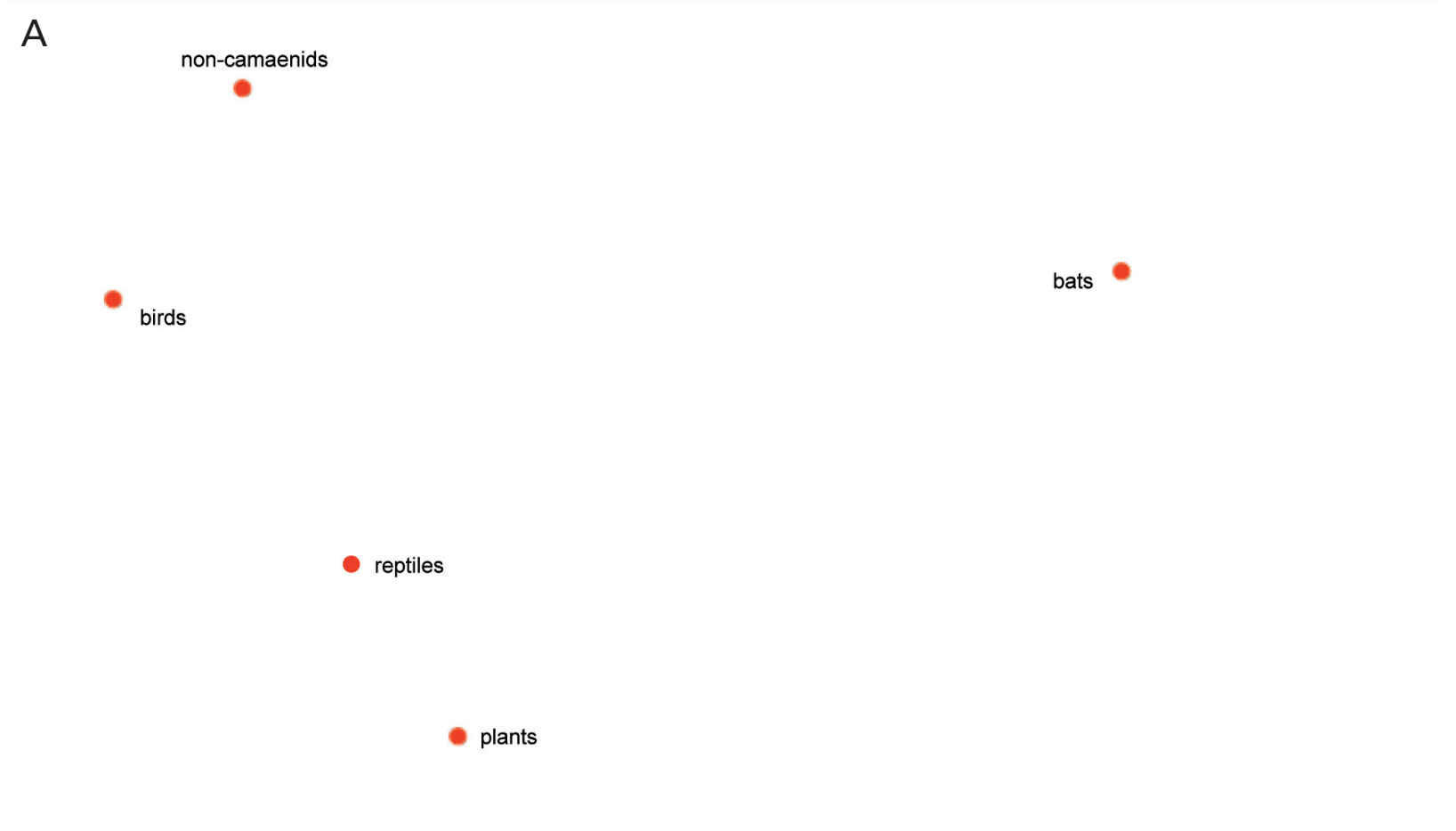

B

camaenids

non camaenids birds

reptiles bats

FIGURE 2 Non-metric MDS plot of Mantel correlation coefficients showing similarity in spatial patterns between the taxonomic groups sampled for A) congruent groups (stress $=0.001$ ) and B) all groups (stress $=0.001$ ). 


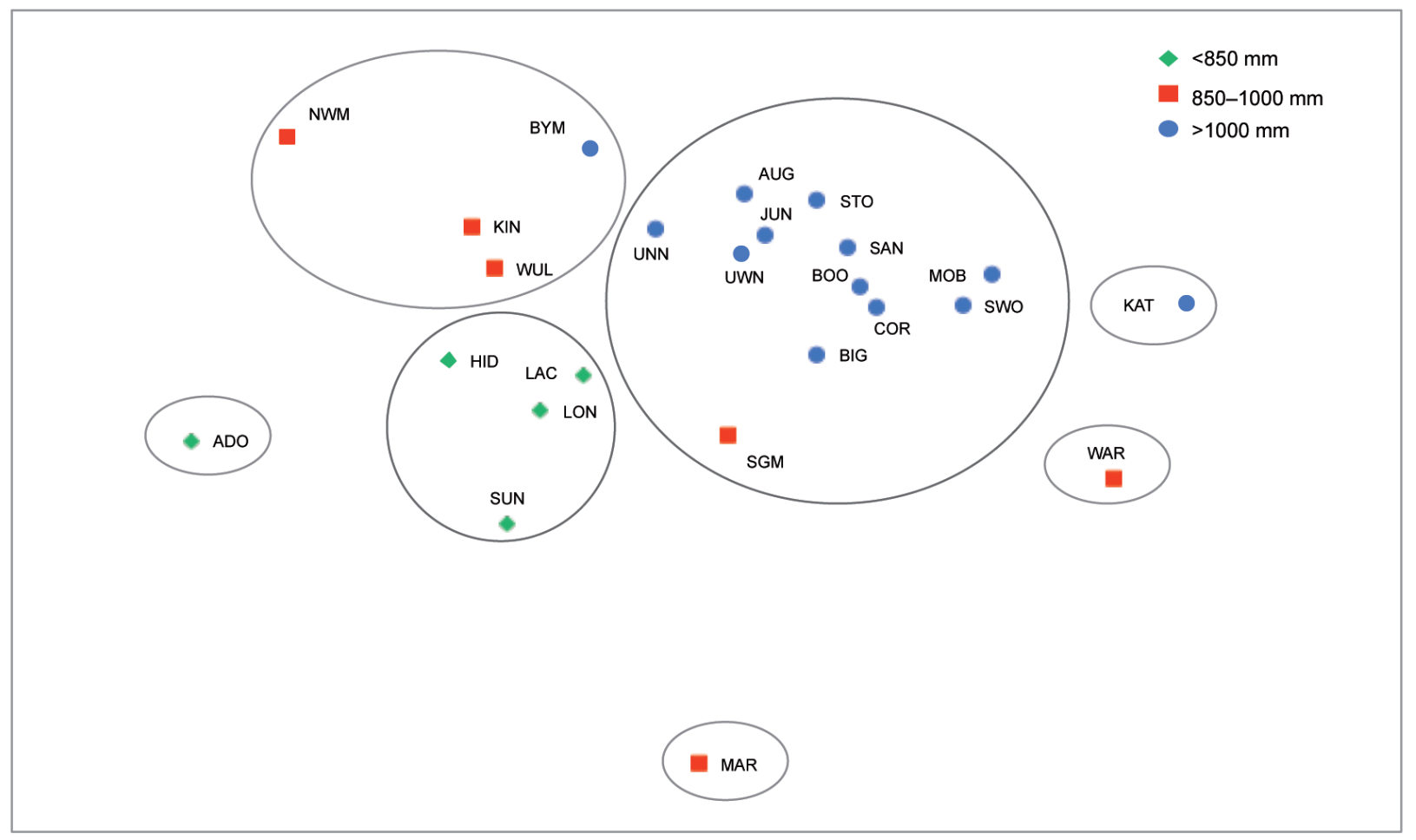

FIGURE 3 Non-metric MDS plot of compositional patterns of congruent taxonomic groups (i.e. bats, birds, noncamaenid land snails, reptiles and plants) across the Kimberley islands sampled, based on the Sørensen similarity matrix (2D stress $=0.17$ ). Three rainfall bands (low: $<850 \mathrm{~mm}$, moderate: $850-1000 \mathrm{~mm}$, high: $>1000 \mathrm{~mm}$ ) are indicated by dot shape and colour on the plot. Clusters at the $40 \%$ similarity level are indicated by ellipses.

Key: ADO - Adolphus, AUG - Augustus, BIG - Bigge, BOO - Boongaree, BYM - Byam Martin, COR - Coronation, JUN - Jungulu, HID - Hidden, KAT - Katers, KIN - Kingfisher, LAC - Lachlan, LON - Long, MAR - Mary, MOB - Middle Osborn, NWM - NW Molema, SGM - Sir Graham Moore, SAN - St Andrew, STO - Storr, SUN - Sunday, SWO - South West Osborn, UNN - Un-named, UWN - Uwins, WAR - Wargul Wargul, WUL - Wulalam Island.

Two of the single-island clusters (Mary and Wargul Wargul) are located along the northern section of the Kimberley coast (Figure 1). While these islands occur within the same rainfall band (i.e. $850-1000 \mathrm{~mm}$ ), they differ substantially in terms of their geomorphology; Mary is a flat sand island and Wargul Wargul is lateritic/volcanic. Both islands were not resampled in the wet season which probably means that their species counts are biased low and potentially explains why they are outliers. The final outlier, Adolphus Island, is a relatively dry island $(<850 \mathrm{~mm})$ which is geographically distant from all of the other islands sampled, being located on the eastern edge of the Northern Kimberley (Figure 1). In contrast to the other islands receiving a similar estimated rainfall in the southern-most section of the Northern Kimberley coastline, the comparatively larger
Adolphus Island (Appendix 1), is one of the more diverse (323 species).

\section{DISCORDANT GROUPS}

The camaenid land snails showed an exceptionally high degree of species turnover between islands suggesting that the species composition of each island was unique. The analysis by Gibson and Köhler (2012) showed that, at the generic level, both average annual rainfall and the extent of rock scree had the strongest association with compositional similarity. Two island clusters were also identified with the majority of islands in one cluster receiving an annual rainfall of greater than $1000 \mathrm{~mm}$, and those islands receiving less than $1000 \mathrm{~mm}$ in the other (i.e. Hidden, Long, Sunday, Mary and Sir Graham 
Moore islands) (see Gibson and Köhler 2012).

When the islands were re-ordered according to similarities in their non-volant mammal composition, three clusters emerged (defined at the $45 \%$ similarity level) (Figure 4). The largest cluster is comprised of 12 islands with generally moderate topographical gradients and largely lacking rugged, deeply-dissected boulder country. With the exception of three islands (Un-named, Coronation and St Andrew), these islands are located in the relatively drier southern and northern-most sections of the Northern Kimberley coastline, receiving less than $1000 \mathrm{~mm}$ average annual rainfall. This cluster also contains the smallest islands and, with the exception of three islands (Sir Graham Moore, Coronation and Adolphus), are less than 1500 ha in size. The remaining two clusters contain islands largely dominated by rugged, deeply dissected boulder country with sheer scarps. All, except Lachlan and South West Osborn, are greater than 1500 ha. All of the islands within one of these clusters are located within the high rainfall (>1000 mm) north-westerly section of the Northern Kimberley coast, while the other includes islands that are also located in the southern drier section of the coast $(<900 \mathrm{~mm})$. The BIOENV analysis reinforced these general observations with the combination of extent of rock scree, island area, annual average rainfall and proximity to river mouth showing the strongest association with compositional similarity (Spearman's rho $=0.37$ ). Species similarity was not significantly correlated with geographic distance among islands (Mantel $\mathrm{r}$ $=-0.05, P=0.28)$.

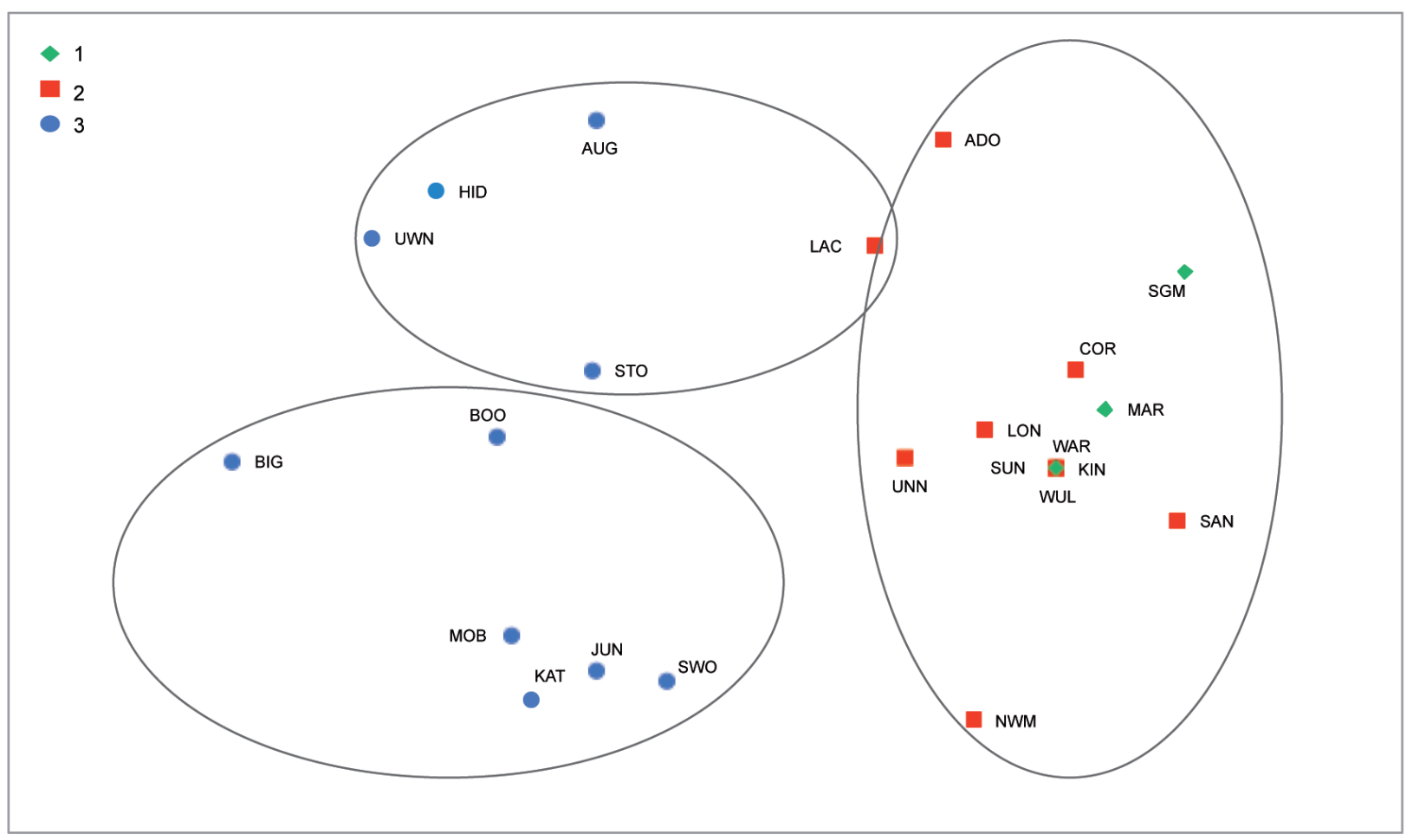

FIGURE 4 Non-metric MDS plot of compositional patterns of non-volant mammals across the Kimberley islands sampled, based on the Sørensen similarity matrix $(2 \mathrm{D}$ stress $=0.15)$. Three categories of the extent of rock scree (low $=1$, moderate $=2$ and high $=3$ ) are indicated by dot shape and colour on the plot. Clusters at the $45 \%$ similarity level are indicated by ellipses.

Key: ADO - Adolphus, AUG - Augustus, BIG - Bigge, BOO - Boongaree, COR - Coronation, JUN - Jungulu, HID - Hidden, KAT - Katers, KIN - Kingfisher, LAC - Lachlan, LON - Long, MAR - Mary, MOB - Middle Osborn, NWM - NW Molema, SGM - Sir Graham Moore, SAN - St Andrew, STO - Storr, SUN - Sunday, SWO - South West Osborn, UNN - Un-named, UWN - Uwins, WAR - Wargul Wargul, WUL - Wulalam Island. Note that SUN (category 2 rock scree), WAR, KIN and WUL (category 1 rock scree) are coincident on the plot, and no mammals were detected on Byam Martin. 


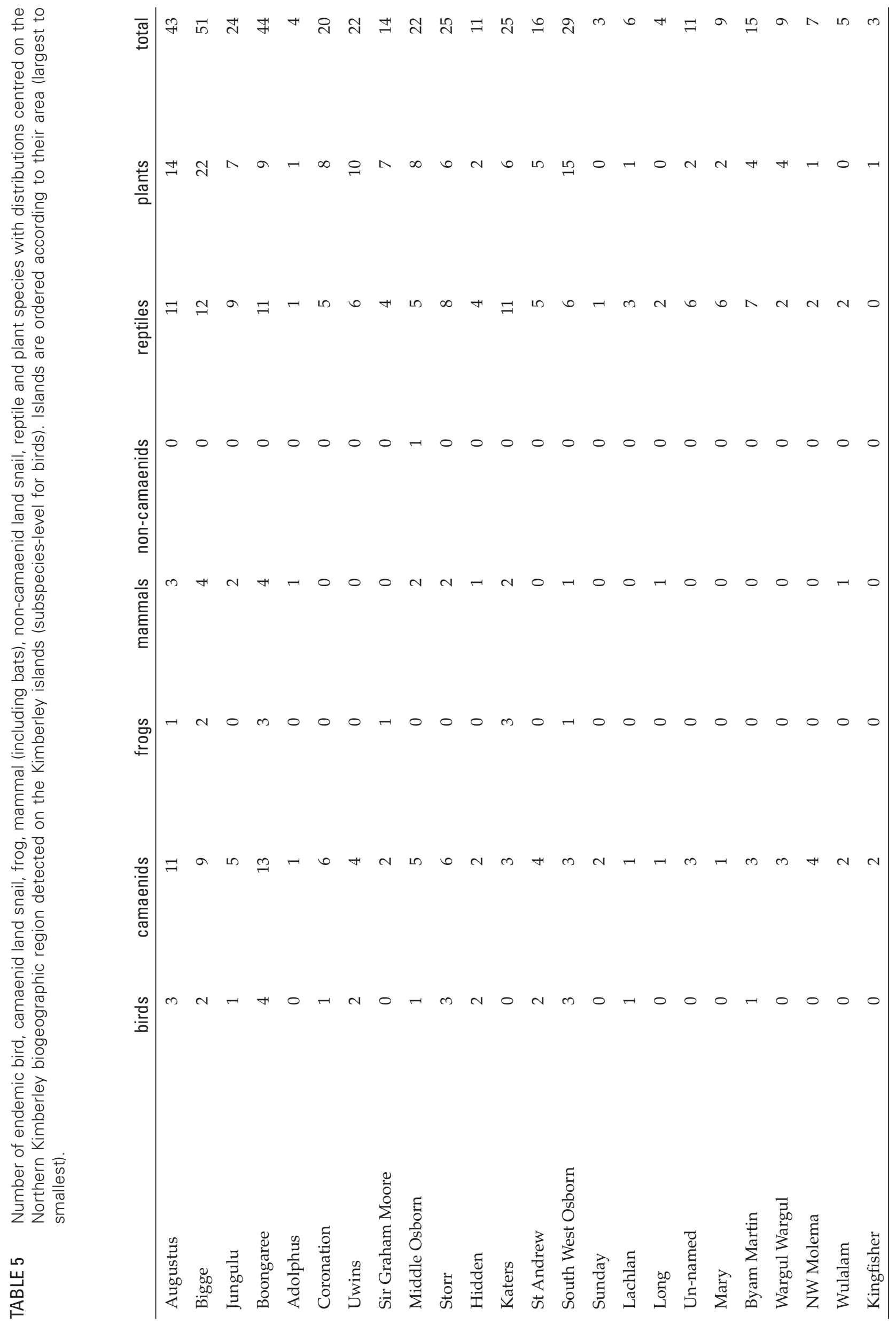


TABLE 6 Results of $\mathrm{AIC}_{c}$-based model selection for the species richness of Northern Kimberley endemic species on the islands sampled during the KIBS (four most supported models shown); also shows maximised loglikelihood function $[\log (L)]$, number of model parameters $(K), A I C$ differences $\left(\Delta_{i}\right)$, Akaike weights $\left(w_{i}\right)$ and percent of deviance explained by each model (\%Dev).

*Model includes variables: area - area of island; dist - distance from mainland; rain - average annual rainfall; river - proximity to river mouth; boulder - extent of rock scree, ele - maximum elevation

\begin{tabular}{lcccccc} 
Model* $^{*}$ & $\log (\mathrm{L})$ & $\mathrm{K}$ & $\mathrm{AIC}_{c}$ & $\Delta_{i}$ & $w_{i} \% \mathrm{Dev}$ \\
\hline $\log ($ area $)+\log ($ dist $)+$ rain+boulder & -69.7 & 5 & 152.7 & 0.00 & 0.48 & 85.3 \\
$\log ($ area $)+\log ($ dist $)+$ rain+river+boulder & -68.9 & 6 & 154.7 & 2.00 & 0.18 & 86.0 \\
$\log ($ area $)+$ boulder+rain & -72.8 & 4 & 155.7 & 3.06 & 0.10 & 82.6 \\
$\log ($ area $)+\log ($ dist $)+$ ele+rain+boulder & -69.7 & 6 & 156.3 & 3.61 & 0.08 & 85.3 \\
\hline
\end{tabular}

\section{RICHNESS OF ENDEMIC SPECIES}

The number of endemic species with distributions centered on the Northern Kimberley biogeographic region on each of the islands sampled, for each of the taxonomic groups, is presented in Table 5. Individual species are listed in Appendix 3.

Richness of the regional endemics ranged from three species on Kingfisher and Sunday islands to 51 on Bigge Island (Table 5). In terms of explaining variation in species richness across all of the islands sampled, the averaged-model performed strongly (Adjusted $R$-square $=0.71, P<0.001$ ). A positive association between the richness of endemic species and average annual rainfall, island area and extent of rock scree, and a negative association with distance to the mainland were all strongly supported (Tables 6 and 7). All these attributes were included in the most supported model, which explained $85.3 \%$ of the deviance (Table 6). Associations with proximity to river mouth and maximum elevation were weakly supported (Tables 6 and 7).

\section{DISCUSSION}

\section{DATA AND ANALYSIS LIMITATIONS}

While the KIBS was the first survey to include wet and dry season systematic sampling on the Kimberley islands, and involved the most intensive sampling strategy to date, there is one main caveat regarding the analysis and interpretation of the data compiled; and that is the completeness of the island species lists. False absences are highly likely given the limited number of sites that could be logistically sampled on an island. To reduce the incidence of false absences, historical records of species occurrence (where available) were included in the analyses. However in doing so, uneven sampling effort between the islands then potentially becomes an issue. This was a clear problem with the plant data (M. Lyons pers. comm.), so additional non-survey plant records were excluded. Pair-wise Pearson correlations between survey effort (i.e. number of known surveys including the KIBS; Appendix 4) and species richness of the other groups that contained historical species records (i.e. birds, bats, reptiles and non-volant mammals) indicated a moderate influence of survey effort (i.e. birds: 0.57; bats: 0.51; reptiles: 0.55; non-volant mammals: 0.56). The relatively larger islands such as Augustus, Bigge and Boongaree tended to be the focus of previous surveys, however correlations between island area and survey effort were low to moderate (bats: 0.37; birds: 0.56; reptiles: 0.57; non-volant mammals: $0.62)$, suggesting a limited bias. The likelihood of false absences and their implications, as well as the adequacy of the sampling more generally, are further discussed in the relevant papers focusing on each taxonomic group (see Doughty et al. 2012; Gibson and Köhler 2012; Gibson and McKenzie 2012b; McKenzie and Bullen 2012; Pearson et al. 2013; Palmer et al. 2013; Lyons et al. 2013). While our knowledge on each of the taxonomic groups we sampled on individual islands is likely to be incomplete, the KIBS substantially improved this knowledge, and the analyses revealed strong 
patterns between community similarity and island attributes.

\section{PATTERNS IN SPECIES RICHNESS}

A high level of congruence in spatial patterns of species richness was apparent across most of the taxonomic groups sampled. This finding contrasts with many other studies that have generally found poor congruence in species richness between taxonomic groups (Flather et al. 1997; Howard et al. 1998; Oliver et al. 1998; Gaston 2000; Su et al. 2004; Kati et al. 2004; Wolters et al. 2006; Heino 2010). One other exception is the endemic species of the tropical rainforests of north east Australia; a high level of congruence between the richness of land snails, vertebrates, selected insects and plants across biogeographical subregions was observed (Moritz et al. 2001). These authors attributed the similarity in species richness patterns to an underlying history of climate-induced vicariance (Moritz et al. 2001). A common geographical vicariance event, such as rising sea-levels, is one explanation for congruence among multiple taxonomic groups (Pawar et al. 2007; Bowman et al. 2010). Aside from a common climatic and/ or biogeographical history, strong congruence in species richness patterns can also be explained by similar responses to the same local environmental parameters (Heino 2010).

With respect to islands, species richness is a function of assemblages at the time of isolation, and colonization and extinction (Losos and Ricklefs 2009; Losos and Parent 2010). Geographical factors and regional environmental conditions such as island area, isolation, elevation, topography, habitat heterogeneity and climate, as well as intrinsic factors such as dispersal capability and ecological tolerance are likely to influence the relative importance of these processes (Parent and Crespi 2006). Of these, island area and isolation are considered to be two of the most influential factors on species richness (MacArthur and Wilson 1963, 1967; Lomolino 2000). The species-area relationship is considered to be one of the few 'laws' in ecology (Ricklefs and Lovette 1999). Larger islands are better able to buffer against stochastic extinctions and typically provide greater niche space due to increased habitat heterogeneity (Ricklefs and Lovette 1999; Dennis et al. 2012). Additionally, larger islands have a greater capacity to withstand the effects of major disturbances, such as cyclones and fire, which could devastate entire populations on smaller islands (Rickleffs and Lovette 1999). In the current study, based on the summed Akaike weights, island area was clearly the most important attribute in explaining variation in species richness of bats, birds, non-volant mammals, plants and reptiles, and probably accounts for the strong congruence in richness among these groups. Island area was also strongly correlated with the species richness of frogs. Richness of all these groups increased with increasing island area.

The degree of island isolation influences colonization potential, i.e. the more isolated, the lower the opportunities for colonization (Losos and Ricklefs 2009). Here, I found the effect of island isolation (i.e. distance to the mainland) on species richness was moderately supported for non-volant mammals and, to a lesser degree, reptiles (i.e. second-ranked attribute after area), but only weakly supported for the remaining groups. The negative relationship with the non-volant vertebrates (i.e. decreasing richness with increasing distance from the mainland) is probably explained by rafting and/or swimming of these vertebrates to the nearshore islands. The enormous tidal surges that occur in the Kimberley may also increase accessibility to the islands closer to the mainland across shallow water and mud flats. With the exception of the camaenid land snails, the remaining groups all have high dispersal capacity (including passive

TABLE 7 Model-averaged coefficients $(\beta)$ and unconditional standard errors (SE) for each variable included in the model selection for the species richness of Northern Kimberley endemic species on the islands sampled during the KIBS. Sum of weights for models containing each coefficient $w_{+}$are also shown.

\begin{tabular}{lrrr} 
Variable & $\beta$ & SE & $w_{+}$ \\
\hline Intercept & -2.692 & 0.550 & 1.00 \\
$\log ($ area $)$ & 0.003 & 0.001 & 1.00 \\
rain & 0.588 & 0.142 & 0.94 \\
boulder & 0.257 & 0.094 & 0.82 \\
$\log ($ distance $)$ & -0.221 & 0.102 & 0.25 \\
river & 0.058 & 0.070 & 0.16 \\
elevation & 0.000 & 0.001 & \\
\hline
\end{tabular}


dispersal), and given the relatively small distances between the islands and the mainland (majority less than $4 \mathrm{~km}$ ), colonization into most areas supporting suitable habitat on islands is likely. Yu et al. (2012) reported a similar result for birds and plants on land-bridge islands (i.e. previously connected to the mainland) of the Thousand Island Lake area in China. In general, on land-bridge islands (such as the continental islands of the Kimberley), the 'distance-effect' (i.e. more isolated islands will have fewer species) has shown to hold true only for the least mobile taxa, such as nonvolant mammals (Case and Cody 1987).

Two groups that showed the least congruence with the other groups in terms of spatial pattern in species richness were the camaenid and noncamaenid land snails, which were in themselves strongly correlated. For both groups of land snails, a positive relationship with average annual rainfall was the most important attribute defining species richness. As discussed in Gibson and Köhler (2012), rainfall was highly correlated with extent of rainforest on an island, which is considered optimal habitat for these desiccation-prone organisms (Solem 1991), and is likely to explain this strong positive relationship between richness and rainfall. Gibson and Köhler (2012) also suggested that species richness of the camaenid land snails is largely a function of in situ speciation; a result of limited dispersal capacity and highly disjunct suitable habitat on the islands.

\section{PATTERNS IN ASSEMBLAGE COMPOSITION}

As for species richness on islands, I found significant correlations between community similarity on islands among several of the taxonomic groups (i.e. islands with similar cooccurrences of species within one taxonomic group also had similar co-occurrences of species from another taxonomic group). Several other studies have also reported cross-taxon congruence in community similarity (or complementarity) (e.g. Howard et al. 1998; Oliver et al. 1998; Moritz et al. 2001; Steinitz et al. 2005; Su et al. 2004; Pawar et al. 2007). Dispersal capacity has been shown to influence the degree of cross-taxon congruence in community similarity (Moritz et al. 2001; Graham et al. 2006; Pawar et al. 2007). Similarly here, those that showed the highest level of congruence, also have the greater capacity to colonise islands (i.e. birds, bats, vascular plants, non-camaenid land snails and reptiles). The non-camaenid land snails and many vascular plants have high passive dispersal capacity, including dispersal by birds and bats (Cameron 1992; Solem and McKenzie 1991; Wada et al. 2012). While the reptiles are the least mobile of this group (Case and Cody 1987), the possibility of colonisation of Kimberley islands by reptiles is enhanced by the high incidence of extreme rainfall events (including cyclones), large tides and the abundance of vegetation that can form rafts (Calsbeek and Smith 2003). Overall species turnover (i.e. beta.SOR) for the congruent groups was also similar (range: 0.84-0.87). According to equilibrium theory, land-bridge islands approach equilibrium from above, with extinction exceeding colonization until the two eventually balance (Case and Cody 1987). However, with the more mobile groups, local extinctions are more likely to be compensated for by frequent recolonisation from the mainland (Case and Cody 1987), and may explain the congruence observed among this group. The two discordant groups (i.e. camaenid land snails and non-volant mammals) have relatively poorer capacity for over-water colonisation, particularly the camaenid land snails (Solem and McKenzie 1991; Case and Cody 1987). Overall species turnover among the islands was also higher for these latter groups; in fact there was almost complete turnover of the camaenid land snails between islands (beta.SOR of 0.99).

Congruence in community similarity between taxonomic groups implies similar patterns of biogeography (Howard et al. 1998; Moritz et al. 2001), and justifies pooling the congruent taxonomic groups to examine an overall (or average) pattern in community composition. Aside from geographical distance between islands, average annual rainfall and extent of rock scree on an island appeared to be strong drivers of community similarity. Woinarski (1992) also reported rainfall to be a significant factor defining the assemblages of mammal, reptile and bird species across the north-western Australian mainland. In general, islands with a high average annual rainfall $(>1000 \mathrm{~mm})$ contained a greater number of species that are characteristic of the wettest part of the Kimberley (i.e. central area of its north-west). The association with rainfall is likely to be an indirect effect with rainfall determining the soil moisture, vegetation and productivity at a site (Gaston 2000; Bowman et al. 2010). Rainfall was significantly correlated with the extent of monsoon rainforest on islands. Species associated with this habitat type were well-represented on these islands (e.g. reptiles: Carlia johnstonei; birds: Rainbow Pitta, Orange-footed Scrub Fowl; land snails: Aminopina macleayi and Gastrocopta kessneri; plants: Antidesma ghaesembilla, Elaeodendron melanocarpum, Ganophyllum falcatum and Vitex acuminata) (Johnstone and Burbidge 1991; Kendrick and Rolfe 1991; Kenneally et al. 1991; Solem 1991; Wheeler et al. 1992; Köhler et al. 2012).

Rugged, deeply dissected boulder country with sheer scarps is also a major feature of most of the high-rainfall $(>1000 \mathrm{~mm})$ islands. The high complexity of this rock scree habitat in the 
Kimberley creates a diversity of niche space, particularly for saxicoline species. The ruggedness of these islands also facilitates the persistence of monsoon rainforest, in part due to water seepage along the base of sandstone cliffs, but more particularly by providing protection from fire (Clayton-Greene and Beard 1985). The resulting habitat heterogeneity on these high rainfall islands is reflected in the relatively large number of both widespread generalist species, occurring on a large proportion of islands (e.g. birds: Brown Honeyeater, Black-faced Cuckoo-shrike and Mistletoebird; reptiles: Ctenotus inornatus and Pseudechis weigeli; land snails: Gastrocopta macdonnelli and Westracystis lissus; plants: Calytrix exstipulata, Ficus aculeata, Jasminum didymium and Xenostegia tridentata), and specialist species that are largely restricted to specific habitats such as rainforests and mangroves, and deep gorges, steep escarpments and cliffs, including a number of restricted range endemics (e.g. reptiles: Ctenotus burbidgei, Morelia carinata, Pseudothecadactylus cavaticus, Pogona microlepidota and Gehyra xenopus; birds: Sandstone Shrike-thrush, White-quilled Rock Pigeon, Kimberley Flycatcher and Kimberley White-lined Honeyeater; plants: Acacia kenneallyi, Aponogeton kimberleyensis, Ptilotus decalvatus and Solanum cataphractum) (Smith et al. 1978; Solem 1991; Wheeler et al. 1992; Wilson and Swan 2003; Johnstone and Storr 2004; Köhler et al. 2012).

Sir Graham Moore (with less than $1000 \mathrm{~mm}$ annual rainfall) was included in the cluster of high rainfall islands, presumably due to its high species richness. This island has a diversity of habitat types, including Quaternary sands, sandstone outcrops, a lateritic plateau and a permanent wetland, which is likely to explain the large number of species on this island. It supports many of the widespread species as well as taxa more typical of the drier Kimberley mainland (e.g. reptiles: Strophurus ciliaris and Carlia munda; birds: Grey-fronted Honeyeater, Singing Honeyeater and Little Button-quail; land snails: Gastrocopta pediculus; plants: Acacia platycarpa and Senna oligoclada), and some sand specialists which it shares with Mary Island (e.g. reptiles: Diporiphora magna and Ctenotus mesotes) (Smith et al. 1978; Solem 1999; Wheeler et al. 1992; Johnstone and Storr 2004; Smith et al. 2011).

The lower rainfall islands located along the southern section of the coastline are generally less diverse than those above. However, the assemblages on these islands are not just subsets of the wetter islands as indicated by the low 'nestedness' values (i.e. beta.NES). The one exception was the non-camaenid land snails whereby a cohort of species occurred across all islands, regardless of rainfall, while another appeared to be largely restricted to high rainfall islands. These island groups contain species that have distributions that extend into semi-arid and arid areas (e.g. reptiles: Lerista greeri, L. griffini and Varanus glebopalma; birds: Australian Kestral, Little Eagle and Australian Owlet-nightjar; land snails: Gastrocopta macdonnelli and Eremopeas interioris; plants: Templetonia hookeri and Acacia hippuroides) (Johnstone and Storr 1998; Storr et al. 1999; Wilson and Swan 2003; Köhler et al. 2012) and includes examples where species of the high rainfall zone of the Northern Kimberley have been replaced by drier area species (e.g. the gecko Gehyra xenopus was replaced by G.occidentalis; see Palmer et al. 2013). These islands also lack well-developed monsoon rainforest and consequently species restricted to that habitat type.

At least two of the three single-island outliers are probably best explained by sampling bias (i.e. Wargul Wargul and Mary Islands were not resampled in the wet season). Mary Island does differ from the other islands in being 'flat' and sandy, with few rock outcrops. Another notable outlier, but with relatively high diversity, was Adolphus Island, which is located well to the east of all the other islands, in a comparatively low rainfall zone $(<850 \mathrm{~mm})$. This island includes many widespread species, as well as a variety of species from drier, warmer habitats typical of the mainland east Kimberley, including species not recorded on the other islands sampled (e.g. reptiles: Varanus panoptes panoptes and Ctenotus robustus; birds: Spinifex Pigeon, Red-backed Kingfisher and Red-chested Button-quail; plants: Allopterigeron filifolius, Brachychiton incanus, Mirbelia viminalis and Sphaeranthus africanus) (Wheeler et al. 1992; Johnstone and Storr 1998; Storr et al. 1999; Johnston and Storr 2004), and lacks rainforest taxa. Potter et al. (2012) recently identified a new potential biogeographic barrier in the central Kimberley - the East-West Kimberley Divide. Adolphus is the only island we sampled that is located on the eastern side of this barrier (see Eldridge et al. 2011).

Among the discordant groups, the compositional pattern of the non-volant mammals appears to be more strongly driven by the substrate of the islands and island area. The islands with the most rugged rocky habitats are characterised by species that have been shown to be associated with that habitat type on the mainland (e.g. Dasyurus hallucatus and Zyzomys woodwardi) (McKenzie et al. 1975; Bradley et al. 1987; Friend et al. 1991; Van Dyck and Strahan 2008). Among these more rugged islands, there appears to be two distinct groups, one that supports species that will tolerate drier climates (e.g. Isoodon auratus and Mesembriomys macrurus) (McKenzie 1981) and the other including species that are largely restricted to high rainfall areas (e.g. Wyulda 
squamicaudata and Petrogale burbidgei) (Burbidge and Webb 2008; Pearson et al. 2008). These two island groups also include the largest islands (e.g. Augustus, Bigge and Boongaree) and this is reflected by the greater diversity of non-volant mammal species detected on them, and presumably due to the more heterogeneous habitat (Ricklefs and Lovette 1999). With a few exceptions, the remaining group of predominantly small islands lack deeply dissected rocky terrain. They are characterised by the presence of Melomys burtoni, a largely arboreal rodent that is not reliant on rocky outcrops (McKenzie et al. 1975; Bradley et al. 1987), which was detected on all of the islands in this group except NW Molema. Other species associated with slopes and valleys with deep soil profiles (e.g. Isoodon macrourus), and clay and/or sandy plains on the mainland (e.g. Sminthopsis virginiae, Macropus agilis and Pseudomys nanus) (McKenzie et al. 1975; Bradley et al. 1987; Bowman et al. 2010) were only detected on the islands sampled within this group.

As discussed above, the high level of species turnover between islands of camaenid land snails suggests that each island has a unique assemblage. At the coarser taxonomic resolution of genera, compositional pattern is influenced by a rainfall gradient, with two island clusters evident (see Gibson and Köhler 2012). The implications of this pattern are discussed further below.

\section{ENDEMICS ON ISLANDS}

Very few vertebrate and plant species detected during the KIBS were endemic to islands. There were only 10 vertebrate species recorded on the islands that do not have known mainland distributions, all reptiles (Palmer et al. 2013). However, it is likely that they have not been recorded on the adjacent mainland due to the lack of sampling along the Kimberley coastline, as all 10 species were on near-shore islands. Six plant species are only known from the islands, one of which was detected during the KIBS, the others are Western Australian Herbarium records from prior surveys (Lyons et al. 2013).

For species to form on islands, colonization rates must be low enough so that island populations are not swamped by gene flow from colonising populations (Case and Cody 1987). More distant islands are likely to experience less gene flow due to lower opportunities for colonization, thereby increasing the likelihood for in situ speciation (Losos and Ricklefs 2009; Losos and Parent 2010). The close proximity of the Kimberley islands to the mainland probably explains the lack of vertebrate and plant species endemic to these islands. Evidence for gene flow between the Kimberley mainland and islands is provided by the study of How et al. (2009); the genetic diversity of $D$. hallucatus populations on near-shore islands was more similar to the mainland than the islands separated by long-term sea channels. Modest levels of local endemism on other land-bridge islands have been documented, but only in the least mobile taxa (i.e. reptiles and non-volant mammals), and there was no evidence of endemism among the groups with generally higher dispersal capacity (i.e. plants and birds) (Case and Cody 1987).

However among the camaenid land snails, 73 of the 89 species detected were endemic to the islands, and 62 of those were single-island endemics. As discussed above, Gibson and Köhler (2012) propose that due to the limited capacity for dispersal of the camaenid land snails, this level of endemism is largely a result of in situ (or within-island) speciation. This is also supported by Johnson et al. (2010) who, focusing on the camaenid genus Amplirhagada from parts of the Bonaparte Archipelago in the Kimberley, found that these island populations have remained resistant to gene flow, despite periodic connections among islands and only small distances separating them. It is likely that camaenid species are restricted to habitat patches on the islands (such as monsoon rainforests), and if these habitats remain disjunct even when connected to the mainland or other islands, then gene flow is less likely (Johnson et al. 2010; Köhler 2010). Such restricted gene flow is likely to encourage allopatric differentiation among islands and speciation within islands.

The endemic fauna of the Northern Kimberley (NK) region is well represented on the islands with all five mammals (including one bat), 29/31 reptiles, 6/7 frogs and 5/9 bird species (sub-species level for birds) detected. Additionally, 64/273 NK plant endemics were detected on the islands. Overall richness of NK endemics on the islands was strongly associated with average annual rainfall and extent of rock scree; with the higher rainfall and more rugged islands tending to support more endemic species. This is in keeping with the pattern on the adjacent mainland whereby the 'hotspots' of endemism occur in the relatively high rainfall areas of the north-western section of the Northern Kimberley (e.g. the Mitchell Plateau and Prince Regent River region) (Woinarski 1992; McKenzie et al. 2009). Woinarski et al. (2006) similarly demonstrated that endemic plant species richness in the Northern Territory was predicted by topographic complexity and rainfall, with higher richness in high-rainfall and topographically complex areas. As discussed above, the high rainfall areas support more monsoon rainforest which is an important resource for many species including numerous endemics (e.g. camaenid land snails and earthworms) (McKenzie et al. 1991). Similarly, there are a number of narrow-range 
endemic species that are known to be restricted to rocky country with deep gorges and steep escarpments (Woinarski et al. 2006; Bowman et al. 2010). More generally, the rugged sandstone formations of the Australian monsoon tropics are known to support a rich assemblage of endemic flora and fauna (Woinarski et al. 2006; Bowman et al. 2010); whereas the surrounding lowland savanna plains tend to exhibit lower levels of endemism (Bowman et al. 2010). This difference has been explained in terms of the buffer from fire and past climate change that the deeply dissected rock landscapes afford (Woinarski et al. 2006; Couper and Hoskin 2008; Bowman et al. 2010). On the Kimberley islands, it is likely that the rocky outcrops have acted as historically stable refugia promoting the persistence of relictual endemic taxa during their periodic isolation from the mainland, particularly for the least mobile fauna such as the frogs, reptiles, non-volant mammals and camaenid land snails. Graham et al. (2006) demonstrated that for low-dispersal endemic rainforest taxa in the wet tropics of Queensland, historical habitat stability was the most important factor explaining spatial patterns of species richness.

Regional endemic richness also tended to increase with island area and decrease with distance from the mainland which is consistent with biogeographic patterns on land-bridge islands observed for overall species richness.

\section{CONSERVATION IMPLICATIONS}

The results of the KIBS support the hypothesis that these islands are microcosms of the adjacent Northern Kimberley mainland, and highlight their importance as natural refuges for mainland biota. Based on current estimates of species numbers, $74 \%$ of mammal, $59 \%$ of reptile, $70 \%$ of frog, $69 \%$ of bird and $49 \%$ of plant species of the Northern Kimberley bioregion are now known on the islands sampled.

In terms of conservation significance, the larger islands are clearly important as they support the highest number of species (including regional endemics), and this applies across all the taxonomic groups sampled, with the exception of the land snails. However, as measures of species richness do not include information on the identity of individual species, they do not provide information regarding species representation across islands (Su et al. 2004; Arponen et al. 2008). Measures of community similarity (or dissimilarity) between pairs of sites (or beta diversity) are more informative in terms of the representativeness of the biodiversity across an area (Ferrier 2002). Here, I found that average annual rainfall and the extent of rock scree on an island appeared to be strong correlates of spatial patterns in community similarity. This pattern was not explained by the loss of species between islands, but largely due to species replacement (or turnover) among islands. As discussed above, this pattern is likely explained by the greater diversity of endemic species and/ or habitat specialists that are restricted to specific habitats such as the deeply dissected rocky country and/or the monsoonal rainforests on the relatively high rainfall and extensively rocky islands; whereas, the drier islands typically support widespread generalists that have distributions that extend into the semi-arid/arid zone. Gibson et al. (2012), in examining plant diversity of ironstone ranges, and finding a similar pattern, suggested that prevalence of generalist species in arid areas is a result of their broader environmental tolerances and/or the occurrence of stochastic extinction of more specialist species in these drier climates.

Restricted-range species are often pivotal in the establishment of conservation reserve systems that focus on complementarity, particularly 'hotspots' of endemism (Pressey et al. 1994; Moritz et al. 2001; Woinarski et al. 2006). So, while the high rainfall islands $(>1000 \mathrm{~mm})$ were more similar in terms of their community composition, they also contained the highest number of Northern Kimberley (NK) endemic species (range: 11-51), and this is particularly true of Augustus, Bigge and Boongaree islands (43, 51 and 44 endemics, respectively). A high number of NK endemics (25) were also recorded on Katers Island, despite this island being relatively poor in total species richness. Of the low rainfall islands $(<850 \mathrm{~mm})$ showing closest similarity in community composition, Hidden Island had the highest richness of NK endemics (range: 3-11). The most speciose island with a unique assemblage (Adolphus) had only four NK endemics. While the low rainfall islands are less species rich and have few endemics, some of them are important refuges for threatened mammal species (e.g. Dasyurus hallucatus and Mesembriomys macrurus on Hidden, and M. macrurus and Isoodon auratus on Lachlan), as well as those that have suffered extensive contractions of their mainland distributions (e.g. Rattus tunneyi on NW Molema) (see Gibson and McKenzie 2012b).

However, the most significant result regarding the conservation importance of the islands comes from the camaenid land snails. The high level of island endemism of the camaenid land snails (many being unique to a single island), along with the fact that there was almost complete turnover of species between islands, indicates that all the islands sampled are important in terms of representing the diversity of the camaenid land snail fauna.

\section{OTHER CONSERVATION CONSIDERATIONS}

While we did not focus our sampling efforts on 
mangrove habitats their conservation importance in the context of the islands should not be ignored. In the Kimberley and Top End of the Northern Territory, mangroves support vertebrates more typically associated with the rainforests of northeastern Queensland (Bowman et al. 2010), including distinct species and sub-species (specifically among the birds and bats) that appear to be more dependent on mangroves than their eastern equivalents (Ford 1982; Johnstone 1990; McKenzie et al. 1991; Eldridge et al. 2011). In north-western Australia, closed-forest mangrove communities are believed to have acted as historical refugia for rainforest fauna when the rainforests contracted as a result of aridification during the last glacial maximum of the Pleistocene (Nix and Kalma 1972; Barlow and Hyland 1988; McKenzie et al. 1991). Some examples of taxa strongly associated with mangroves on the Kimberley islands include birds such as the Kimberley Flycatcher, Largebilled Gerygone and Mangrove Robin, and bats such as Scotorepens sanborni, Mormopterus loriae cobourgiana and Pipistrellus westralis (McKenzie and Rolfe 1986; McKenzie et al. 1991; Johnstone 1990; McKenzie and Bullen 2012). The more extensive mangrove stands on the islands sampled during the KIBS tended to be in the southern section of the Northern Kimberley coastline, for example, Sunday, Kingfisher, Wulalam and Long islands. Some of the more mesic islands such as Boongaree and Storr also support good stands (see Appendix 4 in Gibson and McKenzie 2012b).

That we found little evidence of introduced species on the Kimberley islands (Gibson and McKenzie 2012b; Palmer et al. 2013; Lyons et al. 2013) is no reason to be complacent, as highlighted by Woinarski et al. (2011b). Introduction of feral cats (Felis catus) and colonisation by rafting of the Cane Toad (Rhinella marinus) to the Sir Edward Pellew island group in the Northern Territory coincided with the loss of a high proportion of the terrestrial mammal fauna species, and consequently, the islands' formerly high conservation significance (Woinarski et al. 2011b). Like the islands of the Pellew group, most of the islands along the Kimberley coast are in close proximity to the mainland, and several are located at the entrance of river mouths, increasing the risk of natural invasion by cane toads. Cane toads have already been detected on the mainland close to Adolphus Island in the east Kimberley (D. Pearson pers. comm.). As this island is situated within a major river mouth, toads could potentially raft to this island during the next wet season. Several species known to be susceptible to poisoning by ingestion of toads were detected on islands, including the carnivorous marsupial Dasyurus hallucatus (detected on Adolphus Island; Gibson and McKenzie 2012b), six species of varanid reptiles, the large skink
Tiliqua scincoides and the Death Adder (Acanthophis praelongus) (see Palmer et al. 2013). As such, strategies to prevent the introduction of cane toads to the islands, particularly those with 'cane-toad susceptible' species, as well as regular surveillance to detect and eradicate them should they naturally colonise the islands are crucial.

More generally, the increasing human activity along the Kimberley coastline, primarily associated with resource extraction, pearling, fishing and tourism, all increase the risk of exotic species being introduced to islands. Many pest species can 'hitch-hike' on vessels and consequently invade islands; good examples are cane toads, the Asian House Gecko (Hemidactylus frenatus) and non-native rodents in general (Ecosure 2009). Additionally, visitors to islands can inadvertently introduce weeds via seeds hidden in clothing and/ or equipment. Once incursions of pest species occur, eradication can be difficult and strategies to remove them expensive (Nias et al. 2010; Walshe et al. 2011). In the Kimberley, introduced black rats (Rattus rattus) were successfully eradicated from the Lacepede Islands. However, the Pacific rat (Rattus exulans) on Adele Island remains extant and eradication attempts are ongoing (CCWA 2010). Black rats may also occur on Sunday Island, although they were not detected during the KIBS. Clearly, a biosecurity protocol similar to that being implemented on Barrow Island off the Pilbara coast of Western Australia (Chevron 2011), along with an educational program that highlights the issues, is essential to minimise the risk of introducing exotic species to islands (CCWA 2010; Nias et al. 2010). The biological information compiled during the KIBS can contribute to a biosecurity risk assessment, including ranking islands according to the likelihood of incursion by non-native species.

Increasing human visitation on the islands may also result in increased fire frequency (purpose-lit and accidental). Fires occurring in the dry season can burn across entire islands and have significant consequences on the island biota. Wet season fires (such as those likely to be lightning-ignited), however, probably have less impact as rainfall and damp habitats are likely to limit the fire spread. The role of fire in shaping biological communities on Kimberley islands is unclear. Historically, Aboriginal people used fire on islands for various reasons, although this became infrequent as people moved to settlements (Vigilante et al. 2013). With lessons learned from the mainland (DEC 2009), it is clear that the use of fire on islands must be carefully considered to ensure that the biodiversity values are maintained.

Verification of the significant biodiversity values of the larger Kimberley islands is provided by the results of the KIBS. Further to this are the 
important cultural and traditional values of the islands as highlighted by Vigilante et al. (2013). Future management of the islands is likely to be dependent on mutually agreed strategies that protect both the biodiversity and cultural values of the Kimberley islands.

\section{ACKNOWLEDGEMENTS}

The Kimberley Island Biodiversity Survey involved many people and my heartfelt thanks go to colleagues from the Department of Parks and Wildlife (DPaW), Western Australian Museum, Australian Museum, Kimberley Land Council and Biota Environmental Sciences, the participating Traditional Owners, Aboriginal Rangers and base camp volunteers who contributed to the successful implementation of the field work. I thank the crew of $M V$ Kimberley Escape, MV Odyssey and pilots from Heliwork and Broome Helicopters for transporting teams safely. Andrew Burbidge kindly assisted with the initial helicopter logistics and Tony Start coordinated the first field survey. I am grateful to the DPaW Kimberley Regional Manager Daryl Moncrieff and West Kimberley District Manager Alan Byrne and their staff in the Kununurra and Broome Districts for their support and assistance during the project. DPaW staff based at the Mitchell River National Park (particularly Lindsay Baker and John Hayward) provided valuable logistical support. The project was possible through a research agreement with the Kimberley Land Council for the Balanggarra, Bardi-Jawi, Wanjina-Wunggurr Dambimangari, Mayala and Wanjina-Wunggurr Uunguu native title groups. I am grateful to John Woinarski, David Pearson, Norm McKenzie, Tom Vigilante and one anonymous reviewer for valuable comments on the manuscript. Funding was provided by the Natural Heritage Trust and the Western Australian Department of Parks and Wildlife.

\section{REFERENCES}

Arponen, A., Moilanen, A. and Ferrier, S. (2008). A successful community-level strategy for conservation prioritization. Journal of Applied Ecology 45: 1436-1445.

Barlow, B.A. and Hyland, B.P.M. (1988). The origins of the flora of Australia's wet tropics. Proceedings of the Ecological Society of Australia 15: 1-17.

Baselga, A. (2010). Partitioning the turnover and nestedness components of beta diversity. Global Ecology and Biogeography 19: 134-143.

Bowman, D., Brown, G., Braby, M., Brown, J., Cook, L., Crisp, M., Ford, F., Haberle, S., Hughes, J. and Isagi, Y. (2010). Biogeography of the Australian monsoon tropics. Journal of Biogeography 37: 201-216.

Bradley, A.J., Kemper, C.M., Kitchener, D.J., Humphreys, W.F. and How, R.A. (1987). Small mammals of the Mitchell Plateau Region, Kimberley, Western
Australia. Australian Wildlife Research 14: 397-413.

Burbidge, A.A. (1999). Conservation values and management of Australian islands for non-volant mammal conservation. Australian Mammalogy 21: 67-74.

Burbidge, A.A. and Manly, B. (2002). Mammal extinctions on Australian islands: causes and conservation implications. Journal of Biogeography 29: 465-473.

Burbidge, A.A. and McKenzie, N.L. (1978). The islands of the north-west Kimberley: Western Australia. Wildlife Research Bulletin Western Australia No. 7. Department of Fisheries and Wildlife: Perth.

Burbidge, A.A. and Webb, M.J. (2008). Scaly-tailed possum, Wyulda squamicaudata (pp 277-278). In: S. Van Dyck, and R. Strahan (eds), The Mammals of Australia, 3rd edition. Reed New Holland: Sydney.

Burbidge, A.A, McKenzie, N.L. and Kenneally, K. (1991). Nature conservation reserves in the Kimberley, Western Australia. Department of Conservation and Land Management: Perth.

Burbidge, A.A., Williams, M.R. and Abbott, I. (1997). Mammals of Australian islands: factors influencing species richness. Journal of Biogeography 24: 703-715.

Burnham, K.P. and Anderson, D.R. (2002). Model selection and multimodel inference: a practical information-theoretic approach, 2nd edition. Springer: New York.

Cameron, R. (1992). Land snail faunas of the Napier and Oscar Ranges, Western Australia; diversity, distribution and speciation. Biological Journal of the Linnean Society 45: 271-286.

Calsbeek, R. and Smith, T.B. (2003). Ocean currents mediate evolution in island lizards. Nature 426: 552-555.

Case, T.J. and Cody, M.L. (1987). Testing theories of island biogeography. American Scientist 75: 402-411.

CCWA (2010). Status performance assessment: biodiversity conservation on Western Australian islands. Phase II - Kimberley islands. Unpublished report to the Conservation Commission of Western Australia. The Government of Western Australia: Perth.

Chevron Australia Pty Ltd (2011). Barrow Island Quarantine: Terrestrial and Marine Quarantine Management System. http://www.chevronaustralia. com/Libraries / Chevron_Documents / Gorgon_ Project_Terrestrial_and_Marine_Quarantine_ Management_System.pdf.sflb.ashx. Accessed 11 September 2012.

Clarke, K.R. and Gorley, R.N. (2006). PRIMER v6: User Manual/Tutorial. PRIMER-E Ltd: Plymouth.

Clayton-Greene, K.A. and Beard, J.S. (1985). The fire factor in vine thicket and woodland vegetation of the Admiralty Gulf region, north-west Kimberley, Western Australia. Proceedings of the Ecological Society of Australia 13: 225-230.

Couper, P.J. and Hoskin, C.J. (2008). Litho-refugia: the importance of rock landscapes for the long-term persistence of Australian rainforest fauna. Australian Zoologist 34: 554-560.

DEC (2009). A synthesis of scientific knowledge to support conservation management in the Kimberley region of Western Australia. Department of Environment and Conservation: Perth. 
Dennis, R.L., Hardy, P.B. and Dapporto, L. (2012). Nestedness in island faunas: novel insights into island biogeography through butterfly community profiles of colonization ability and migration capacity. Journal of Biogeography 39: 1412-1426.

Doughty, P., Palmer, R., Cowan, M. and Pearson, D.J. (2012). Biogeographic patterns of frogs of the Kimberley islands, Western Australia. Records of the Western Australian Museum, Supplement 81: 109-124.

Ecosure (2009). Prioritisation of high conservation status offshore islands. Report to the Department of Environment, Water, Heritage and the Arts. Ecosure: Cairns.

Eldridge, M.D.B., Potter, S. and Cooper, S.J.B. (2011). Biogeographic barriers in north-western Australia: an overview and standardization of nomenclature. Australian Journal of Zoology 59: 270-272.

Ferrier, S. (2002). Mapping spatial pattern in biodiversity for regional conservation planning: where to from here? Systematic Biology 51: 331-363.

Flather, C.H., Wilson, K.R., Dean, D.J. and McComb, W.C. (1997). Identifying gaps in conservation networks: of indicators and uncertainty in geographic-based analyses. Ecological Applications 7: 531-542.

Ford, J. (1982). Origin, evolution and speciation of birds specialised to mangroves in Australia. Emu 82: 12-23.

Friend, G.R., Morris, K.D. and McKenzie, N.L. (1991). The mammal fauna of Kimberley rainforests (pp 393-412). In: McKenzie, N.L., Johnston, R.B. and Kendrick, P.G. (eds), Kimberley rainforests of Australia. Surrey Beatty and Sons: Chipping Norton, Australia.

Gaston, K.J. (2000). Global patterns of biodiversity. Nature 405: 220-227.

Geffen, E., Anderson, M.J. and Wayne R.K. (2004). Climate and habitat barriers to dispersal in the highly mobile grey wolf. Molecular Ecology 13: 2481-2490.

Gibson, L.A. and McKenzie, N.L. (2012a). Identification of biodiversity assets of selected Kimberley islands: background and implementation. Records of the Western Australian Museum, Supplement 81: 1-14.

Gibson, L.A. and McKenzie, N.L. (2012b). Occurrence of non-volant mammals on islands along the Kimberley coast of Western Australia. Records of the Western Australian Museum, Supplement 81: 15-40.

Gibson, L.A. and Köhler, F. (2012). Determinants of species richness and similarity of species composition of land snail communities on Kimberley islands. Records of the Western Australian Museum, Supplement 81: 41-66.

Gibson, N., Meissner, R., Markey, A.S. and Thompson, W.A. (2012). Patterns in plant diversity in ironstone ranges in arid south western Australia. Journal of Arid Environments 77: 25-31.

Graham, C.H., Moritz, C. and Williams, S.E. (2006). Habitat history improves prediction of biodiversity in rainforest fauna. Proceedings of the National Academy of Sciences of the USA 103: 632-636.

Heino, J. (2010). Are indicator groups and cross-taxon congruence useful for predicting biodiversity in aquatic ecosystems? Ecological Indicators 10: 112-117.

Houlder, D., Hutchinson, M., Nix, H. and McMahon, J. (2000). ANUCLIM User Guide. Centre for Resource and Environmental Studies. Australian National University: Canberra.

How, R.A., Spencer, P.B.S. and Schmitt, L.H. (2009). Island populations have high conservation value for northern Australia's top marsupial predator ahead of a threatening process. Journal of Zoology 278: 206-217.

Howard, P.C. Viskanic, P., Davenport, T.R.B., Kigenyi, F.W., Baltzer, M., Dickinson, C.J., Lwanga, J.S., Matthews, R.A. and Balmford, A. (1998). Complementarity and the use of indicator groups for reserve selection in Uganda. Nature 394: 472-475.

Island Conservation (2007). Preventing extinctions. www. islandconservation.org. Accessed 14 May 2012.

Kati, V., DeVillers, P., Dufrêne, M., Legakis, A., Vokou, D. and Lebrun, P. (2004). Testing the value of six taxonomic groups as biodiversity indicators at a local scale. Conservation Biology 18: 667-675.

Kendrick, P.G. and Rolfe, J.K. (1991). The reptiles and amphibians of Kimberley rainforests (pp 347-359). In: McKenzie, N.L., Johnston, R.B. and Kendrick, P.G. (eds), Kimberley Rainforests of Australia. Surrey Beatty and Sons: Chipping Norton, Australia.

Kenneally, K.F., Keighery, G.J. and Hyland, B.P.M. (1991). Floristics and phytogeography of Kimberley rainforests, Western Australia (pp 347-359). In: McKenzie, N.L., Johnston, R.B. and Kendrick, P.G. (eds), Kimberley Rainforests of Australia. Surrey Beatty and Sons: Chipping Norton, Australia.

Johnson, M.S., O'Brien, E.K. and Fitzpatrick, J.J. (2010). Deep, hierarchical divergence of mitochondrial DNA in Amplirhagada land snails (Gastropoda: Camaenidae) from the Bonaparte Archipelago, Western Australia. Biological Journal of the Linnean Society 100: 141-153.

Johnstone, R.E. (1990). Mangrove and mangrove birds of Western Australia. Records of the Western Australian Museum Supplement 32: 1-120.

Johnstone, R.E. and Burbidge, A.H. (1991). The avifauna of Kimberley rainforests (pp 361-391). In: McKenzie, N.L., Johnston, R.B. and Kendrick, P.G. (eds), Kimberley Rainforests of Australia. Surrey Beatty and Sons: Chipping Norton, Australia.

Johnstone, R.E. and Storr, G.M. (1998) Handbook of Western Australian Birds. Volume 1: Non-passerines (Emu to Dollarbird). Western Australian Museum: Perth.

Johnstone, R.E. and Storr, G.M. (2004) Handbook of Western Australian Birds. Volume II: Passerines (Blue-winged Pitta to Goldfinch). Western Australian Museum: Perth.

Köhler, F. (2010). Uncovering local endemism in the Kimberley, Western Australia: description of new species of the genus Amplirhagada Iredale, 1933 (Pulmonata: Camaenidae). Records of the Australian Museum 62: 217-284.

Köhler, F., Kessner, V. and Whisson, C. (2012). New records of non-marine, non-camaenid gastropods from islands off the Kimberley coast, Western Australia. Records of the Western Australian Museum 27: 21-39.

Laurance, W.F., Dell, B., Turton, S.M., Lawes, M.J., Hutley, L.B., McCallum, H., Dale, P., Bird, M., Hardy, G., Prideaux, G., Gawne, B., McMahon, C.R., Yu, R., Hero J-M., Schwarzkopf, L., Krockenberger, A., Douglas, M., Silvester, E., Mahony, M., Vella, K., Saikia, U., 
Wahren, C-H., Xu, Z., Smith, B. and Cocklin, C. (2011). The 10 Australian ecosystems most vulnerable to tipping points. Biological Conservation 144: 1472-1480.

Lomolino, M.V. (2000). Ecology's most general, yet protean pattern: the species-area relationship. Journal of Biogeography 27: 17-26.

Losos, J.B. and Ricklefs, R.E. (2009). Adaptation and diversification on islands. Nature 457: 830-836.

Losos, J.B. and Parent, C.E. (2010). The speciation-area relationship (pp 415-438). In: Losos, J.B. and Ricklefs, R.E. (eds), The Theory of Island Biogeography Revisited. Princeton University Press: New Jersey.

Lyons, M.N, Keighery, G.J., Gibson, L.A. and Handasyde, T. (2013). Flora and vegetation communities of selected islands off the Kimberley coast of Western Australia. Records of the Western Australian Museum, Supplement 81: 205-243.

MacArthur, R.H. and Wilson, E.O. (1963). An equilibrium theory of insular zoogeography. Evolution 17: 373-387.

MacArthur, R.H. and Wilson, E.O. (1967). The Theory of Island Biogeography. Princeton University Press: Princeton.

McKenzie, N.L. (1981). Mammals of the Phanerozoic south-west Kimberley, Western Australia: biogeography and recent changes. Journal of Biogeography 8: 263-280.

McKenzie, N.L. and Rolfe, J.K. (1986). Structure of bat guilds in the Kimberley mangroves, Australia. Journal of Animal Ecology 55: 401-420.

McKenzie, N.L. and Bullen, R.D. (2012). An acoustic survey of zoophagic bats on islands in the Kimberley, Western Australia, including data on the echolocation ecology, organization and habitat relationships of regional communities. Records of the Western Australian Museum, Supplement 81: 67-108.

McKenzie, N.L, Chapman, A. and Youngson, W.K. (1975). Mammals of the Prince Regent River Reserve, North-West Kimberley, Western Australia (pp 69-74). In: Miles, J.M. and Burbidge, A.A. (eds), A biological survey of the Prince Regent River Reserve, North-West Kimberley, Western Australia. Wildlife Research Bulletin Western Australia No 3. Department of Fisheries and Wildlife: Perth.

McKenzie, N.L, Johnston, R.B. and Kendrick P.G. (1991). Kimberley Rainforests of Australia. Surrey Beatty and Sons: Chipping Norton, Australia.

McKenzie, N.L., Start, A.N., Burbidge, A.A., Kenneally, K.F. and Burrows, N.D. (2009). Protecting the Kimberley: A synthesis of scientific knowledge to support conservation management in the Kimberley region of Western Australia. Part B: Terrestrial Environments. Department of Environment and Conservation: Perth.

Moritz, C., Richardson, K.S., Ferrier, S., Monteith, G.B., Stanisic, J., Williams, S.E. and Whiffin, T. (2001). Biogeographical concordance and efficiency of taxon indicators for establishing conservation priority in a tropical rainforest biota. Proceedings of the Royal Society of London B 268: 1875-1881.

Nias, R.C., Burbidge, A.A., Ball, D. and Pressey, R.L. (2010). Island arks: the need for an Australian national island biosecurity initiative. Ecological Management and Restoration 11: 166-167.
Nix, H. and Kalma, J. (1972). Climate as a dominant control in the biogeography of northern Australia and New Guinea (pp. 61-91). In: Walker, D. (ed.), Bridge and barrier: the natural and cultural history of Torres Strait. Research School of Pacific Studies Publication E6/3. Australian National University Press: Canberra.

Oliver, I., Beattie, A.J. and York , A. (1998). Spatial fidelity of plant, vertebrate, and invertebrate assemblages in multiple-use forest in eastern Australia. Conservation Biology 12: 822-835.

Parent, C.E. and Crespi, B.J. (2006). Sequential colonization and diversification of Galapagos endemic land snail genus Bulimulus (Gastropoda, Stylommatophora). Evolution 60: 2311-2328.

Palmer, R., Pearson, D.J., Cowan, M.A. and Doughty, P. (2013). Islands and scales: a biogeographic survey of reptiles on Kimberley islands, Western Australia. Records of the Western Australian Museum, Supplement 81: 183-204.

Pawar, S.S., Birand, A.C., Ahmed, M.F., Sengupta, S. and Raman, T.R.S. (2007). Conservation biogeography in North-east India: hierarchical analysis of cross-taxon distributional congruence. Diversity and Distributions 13: 53-65.

Pearson, D.J., Cowan, M.A. and Caton, W. (2013). The avifauna of larger islands along the Kimberley coast, Western Australia. Records of the Western Australian Museum, Supplement 81: 125-144.

Pearson, D.J., Burbidge, A.A., Lochman, J. and Start, A.N. (2008). Monjon Petrogale burbidgei (pp 367-368). In: S. Van Dyck and R. Strahan (eds). The Mammals of Australia, 3rd edition. Reed New Holland: Sydney.

Pressey, R.L., Johnson, I.R. and Wilson, P.D. (1994). Shades of irreplaceability: towards a measure of the contribution of sites to a reservation goal. Biodiversity and Conservation 3: 242-262.

Potter, S., Eldridge, M.D.B., Taggart, D.T. and Cooper, S.J.B. (2012). Multiple biogeographical barriers identified across the monsoon tropics of northern Australia: phylogeographic analysis of the brachyotis group of rock wallabies. Molecular Ecology 21: 22542269.

Ricklefs, R.E. and Lovette, I.J. (1999). The roles of island area per se and habitat diversity in the species-area relationships of four Lesser Antillean faunal groups. Journal of Animal Ecology 68: 1142-1160.

R Development Core Team (2009). R: A language and environment for statistical computing. R Foundation for Statistical Computing, Vienna. URL: http://www.Rproject.org.

Sfenthourakis, S. and Panista, M. (2012). From plots to islands: species diversity at different scales. Journal of Biogeography 39: 750-759.

Smith, L.A. and Johnstone, R.E. (1978). Part V Amphibians and Reptiles (pp 42-45). In: Burbidge, A.A. and McKenzie, N.L. (eds), The islands of the northwest Kimberley: Western Australia. Wildlife Research Bulletin Western Australia No. 7. Department of Fisheries and Wildlife: Perth.

Smith, L.A., Johnstone, R.E. and Dell, J. (1978). Part IV Birds (pp 29-41). In: Burbidge, A.A. and McKenzie, N.L. (eds), The islands of the north-west Kimberley: 
Western Australia. Wildlife Research Bulletin Western Australia No. 7. Department of Fisheries and Wildlife: Perth.

Smith, K.L., Harmon, L.J., Shoo, L.P. and Melville, J. (2011). Evidence of constrained phenotypic evolution in a cryptic species complex of agamid lizards. Evolution 65: 976-992.

Solem, A. (1991). Land snails of Kimberley rainforest patches and biogeography of all Kimberley land snails (pp 145-245). In: McKenzie, N.L., Johnston, R.B. and Kendrick, P.G. (eds), Kimberley Rainforests of Australia. Surrey Beatty and Sons: Chipping Norton, Australia.

Solem, A. and McKenzie N.L. (1991). The composition of land snail assemblages in Kimberley rainforests (pp 247-263). In: McKenzie, N.L., Johnston, R.B. and Kendrick, P.G. (eds), Kimberley Rainforests of Australia. Surrey Beatty and Sons: Chipping Norton, Australia.

Steinitz, O., Heller, J., Tsoar, A., Rotem, D. and Kadmon, R. (2005). Predicting regional patterns of similarity in species composition for conservation planning. Conservation Biology 19: 1978-1988.

Storr, G.M., Smith, L.A. and Johnstone, R.E. (1999). Lizards of Western Australia. I Skinks. Western Australian Museum: Perth.

Su, J.C., Debinski, D.M., Jakubauskas, M.E. and Kindscher, K. (2004). Beyond species richness: community similarity as a measure of cross-taxon congruence for coarse-filter conservation. Conservation Biology 18: 167-173.

Thackway, R. and Cresswell, I.D. (1995). An interim biogeographic regionalisation for Australia: a framework for establishing the national system of reserves. Australian Nature Conservation Agency: Australia.

Van Dyck, S. and Strahan, R. (eds) (2008). The mammals of Australia, 3rd edition. Reed New Holland: Sydney.

Vigilante, T., Toohey, J., Gorring, A., Blundell, V., Saunders, T., Mangolamara, S., George, K., Oobagooma, J., Waina, M., Morgan, K. and Doohan, K. (2013). Island country: Aboriginal connections, values and knowledge of the Western Australian Kimberley islands in the context of an island biological survey. Records of the Western Australian Museum, Supplement 81: 145-181.

Wada, S., Kawakami, K. and Chiba, S. (2012). Snails can survive passage through a bird's digestive system. Journal of Biogeography 39: 69-73.

Walshe, J.C., Venter, O., Watson, J.E.M., Fuller, R.A., Blackburn, T.M. and Possingham, H.P. (2011). Exotic species richness and native species endemism increase the impact of exotic species on islands. Global Ecology and Biogeography 21: 841-850.

Wheeler, J.R., Rye, B.L., Koch, B.L. and Wilson, A.J.G. (1992). Flora of the Kimberley Region. Department of Conservation and Land Management: Como, Australia.

Wilson, S. and Swan, G. (2003). A Complete Guide to Reptiles of Australia. New Holland Publishers: Sydney.

Wolters, V., Bengtsson, J. and Zaitsev, A.S. (2006). Relationship among the species richness of different taxa. Ecology 87: 1886-1895.

Woinarski J.C.Z. (1992). Biogeography and conservation of reptiles, mammals and birds across north-western Australia: an inventory and base for planning an ecological reserve system. Wildlife Research 19: 665705.

Woinarski, J.C.Z., Milne, D.J. and Wanganeen, G. (2001). Changes in mammal populations in relatively intact landscapes of Kakadu National Park, Northern Territory, Australia. Austral Ecology 26: 360-370.

Woinarski, J.C.Z., Palmer, C., Fisher, A., Southgate, R., Masters, P. and Brennan, K. (1999). Distributional patterning of mammals on the Wessel and English Company Islands, Arnhem Land, Northern Territory, Australia. Australian Journal of Zoology 47: 87-111.

Woinarski, J.C.Z., Hempel, C., Cowie, I., Brennan, K., Kerrigan, R., Leach, G. and Russell-Smith, J. (2006). Distributional pattern of plant species endemic to the Northern Territory, Australia. Australian Journal of Botany 54: 627-640.

Woinarski, J.C.Z., Ward, S., Mahney, T., Bradley, J., Brennan, K., Ziembicki, M. and Fisher, A. (2011b). The mammal fauna of the Sir Edward Pellew island group, Northern Territory, Australia: refuge and death-trap. Wildlife Research 38: 307-322.

Woinarski, J.C.Z., Legge, S., Fitzsimmons, J.A., Traill, B.J., Burbidge, A.A., Fisher, A., Firth, R.S.C., Gordon, I.J., Griffiths, A.D., Johnson, C., McKenzie, N.L., Palmer, C., Radford, I., Rankmore, B., Ritchie, E., Ward, S. and Ziembicki, M. (2011a). The disappearing mammal fauna of northern Australia: context, cause and response. Conservation Letters 4: 192-201.

Yu, M., Hu, G., Feeley, K.J., Wu, J. and Ding, P. (2012). Richness and composition of plants and birds on land-bridge islands: effects of island attributes and differential responses of species groups. Journal of Biogeography 39: 1124-1133.

MANUSCRIPT RECEIVED NOVEMBER 2012; ACCEPTED FEBRUARY 2013. 
APPENDIX 1 Values of the island attributes used in species richness and community similarity analyses on Kimberley islands.

Key: area - area of island (ha), distance - distance to the mainland $(\mathrm{km})$, rain - average annual rainfall $(\mathrm{mm})$, boulder - extent of rock scree $(0=$ flat; 1 = rounded, soil-mantled hill slopes and plateaux, narrow scree; 2 = shallow joints, wide ledges, moderate scree; 3 = massive scree, deep joints and scarp country), elevation - maximum elevation (m), river - proximity to river mouth (1 to 5 increasing distance from major river mouth), and mxTwmP - maximum temperature of the warmest period of the year $\left({ }^{\circ} \mathrm{C}\right)$ (not included in the richness analyses).

\begin{tabular}{|c|c|c|c|c|c|c|c|}
\hline & area & distance & rain & boulder & elevation & river & mxTwmP \\
\hline Augustus & 18,929 & 1.79 & 1170 & 3 & 181 & 4 & 34.2 \\
\hline Bigge & 17,108 & 2.97 & 1103 & 3 & 138 & 3 & 34.6 \\
\hline Jungulu & 4803 & 18.91 & 1148 & 3 & 95 & 5 & 33.9 \\
\hline Boongaree & 4164 & 0.14 & 1138 & 3 & 235 & 2 & 35.3 \\
\hline Adolphus & 4134 & 1.96 & 827 & 2 & 244 & 1 & 37.6 \\
\hline Coronation & 3791 & 6.07 & 1141 & 2 & 153 & 5 & 34.8 \\
\hline Uwins & 3219 & 0.23 & 1155 & 3 & 134 & 2 & 34.8 \\
\hline Sir Graham Moore & 2812 & 2.84 & 979 & 1 & 61 & 4 & 34.4 \\
\hline Middle Osborn & 2378 & 2.34 & 1051 & 2 & 240 & 4 & 34.5 \\
\hline Storr & 1883 & 0.26 & 1007 & 3 & 165 & 1 & 35.4 \\
\hline Hidden & 1871 & 1.48 & 839 & 3 & 127 & 4 & 33.2 \\
\hline Katers & 1713 & 1.40 & 1069 & 3 & 101 & 4 & 35.0 \\
\hline St Andrew & 1465 & 2.23 & 1127 & 2 & 284 & 1 & 35.7 \\
\hline South West Osborn & 1340 & 3.07 & 1041 & 3 & 134 & 4 & 34.8 \\
\hline Sunday & 1186 & 8.06 & 778 & 2 & 59 & 3 & 33.2 \\
\hline Lachlan & 1150 & 0.17 & 787 & 2 & 93 & 2 & 33.9 \\
\hline Long & 1125 & 9.36 & 768 & 2 & 65 & 2 & 34.0 \\
\hline Un-named & 897 & 0.69 & 1000 & 2 & 83 & 3 & 35.2 \\
\hline Mary & 847 & 0.68 & 968 & 0 & 11 & 4 & 34.5 \\
\hline Byam Martin & 816 & 13.28 & 1144 & 3 & 69 & 5 & 33.6 \\
\hline Wargul Wargul & 626 & 0.25 & 946 & 1 & 87 & 4 & 33.7 \\
\hline NW Molema & 592 & 1.06 & 881 & 2 & 154 & 3 & 33.4 \\
\hline Wululam & 415 & 0.86 & 901 & 1 & 77 & 2 & 35.3 \\
\hline Kingfisher & 300 & 15.47 & 943 & 1 & 82 & 4 & 34.0 \\
\hline
\end{tabular}




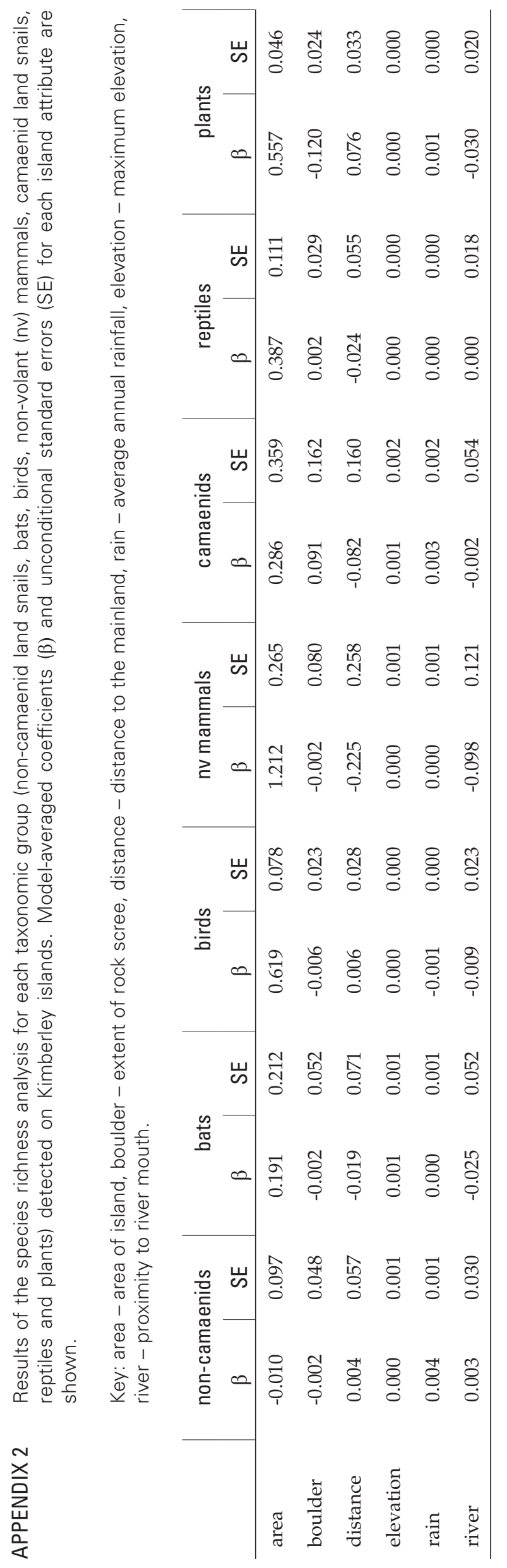




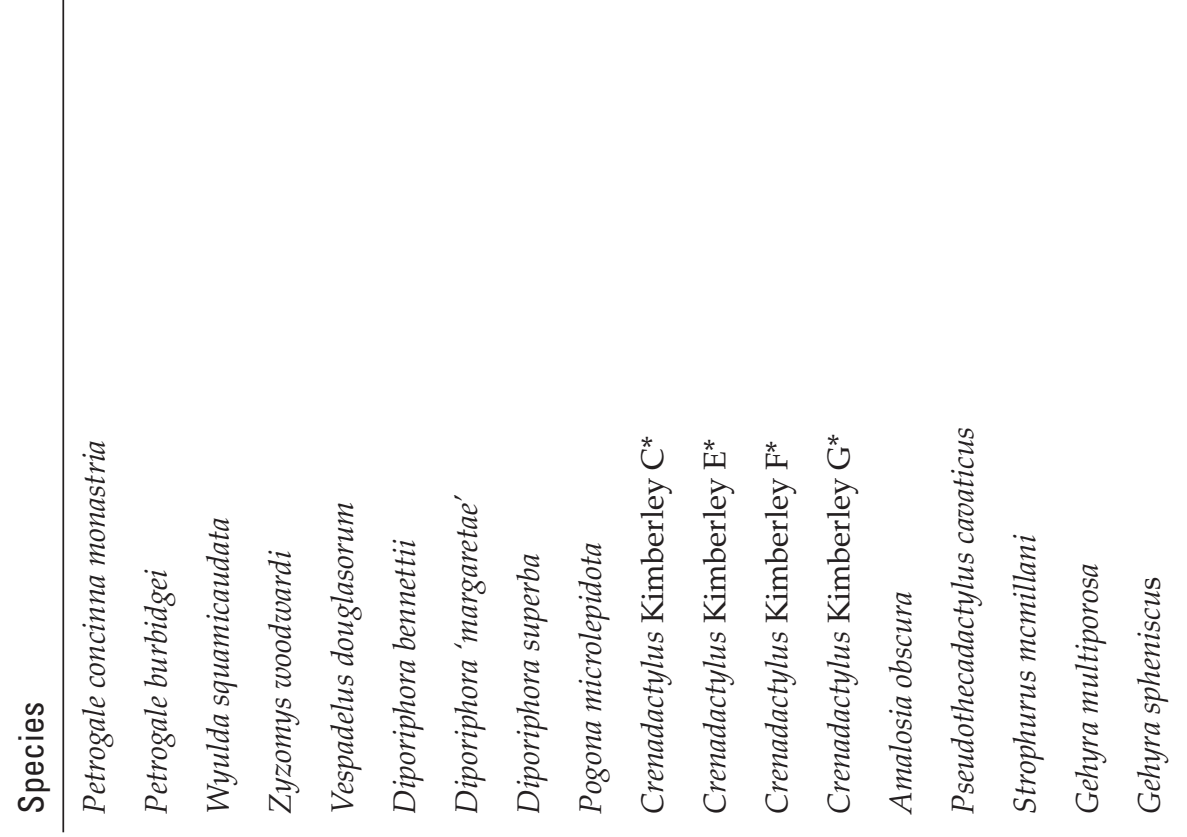




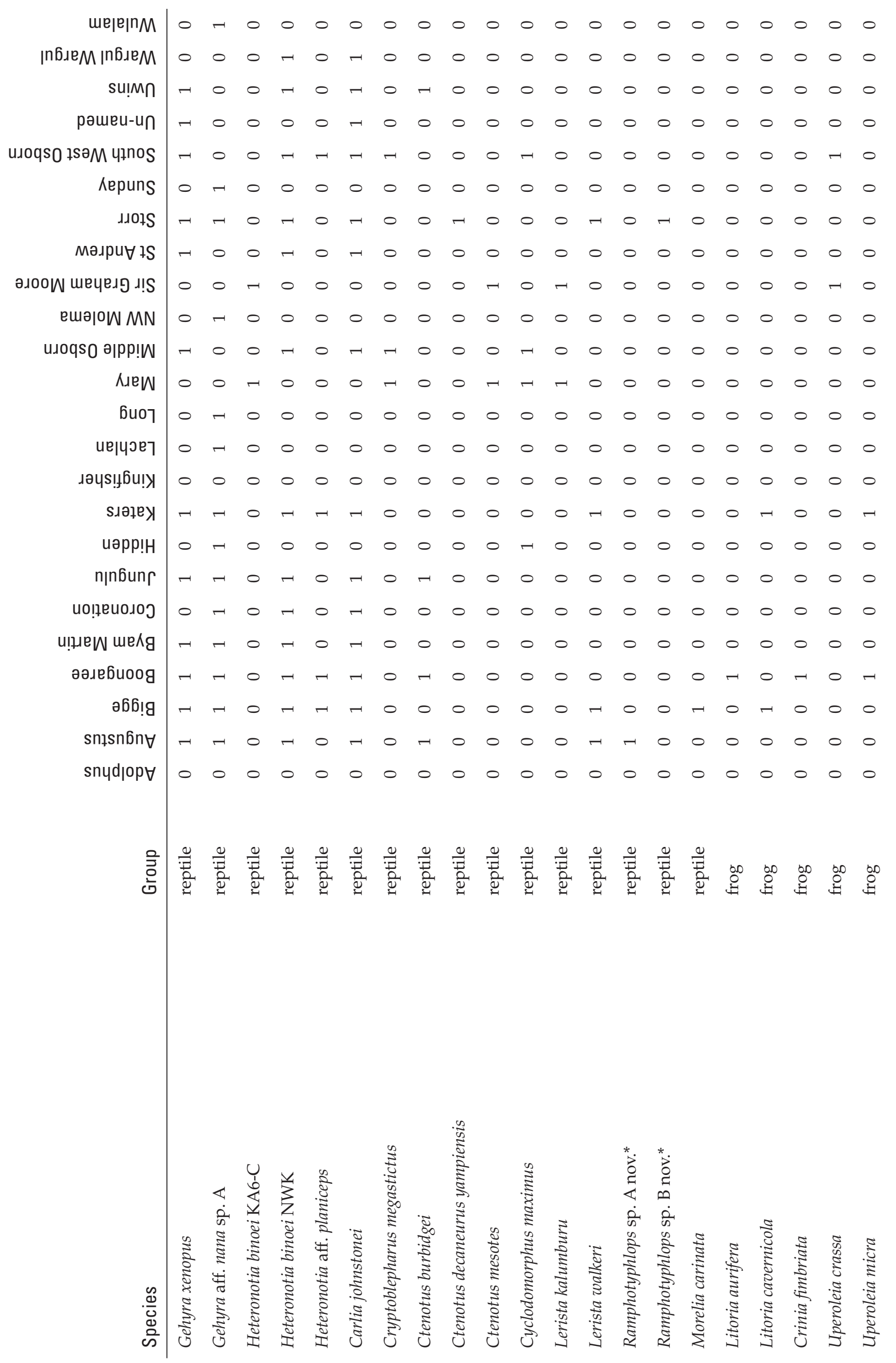




\begin{tabular}{|c|c|c|c|c|c|c|c|c|c|c|c|c|c|c|c|c|c|c|c|c|c|}
\hline mejeןnM & 0 & 0 & 0 & 0 & 0 & 0 & 0 & 0 & 0 & 0 & 0 & 0 & 0 & 0 & 0 & 0 & 0 & 0 & 0 & 0 & 0 \\
\hline Inблем Inблем & 0 & 0 & 0 & 0 & 0 & $\neg$ & 0 & 0 & 0 & 0 & 0 & 0 & 0 & 0 & 0 & 0 & 0 & 0 & 0 & 0 & b \\
\hline su!m & 0 & 0 & 0 & 0 & 0 & 0 & 0 & 0 & 0 & 0 & 0 & 0 & $\circ$ & 0 & 0 & 0 & 0 & 0 & 0 & 0 & - \\
\hline рәшеu-un & 0 & 0 & 0 & 0 & 0 & 0 & 0 & 0 & 0 & 0 & 0 & 0 & $\circ$ & 0 & 0 & $r$ & 0 & 0 & 0 & 0 & 0 \\
\hline uıoqso lsəM yłnos & 0 & 0 & 0 & 0 & 0 & 0 & 0 & 0 & 0 & 0 & $\neg$ & 0 & 0 & 0 & $\circ$ & 0 & 0 & 0 & 0 & 0 & D \\
\hline Nepuns & 0 & 0 & 0 & 0 & 0 & 0 & 0 & 0 & 0 & 0 & 0 & 0 & 0 & 0 & 0 & 0 & 0 & 0 & 0 & 0 & 0 \\
\hline גנOІS & 0 & 0 & 0 & 0 & $\circ$ & 0 & 0 & 0 & 0 & $\circ$ & $\circ$ & 0 & $\circ$ & $\circ$ & 0 & 0 & $\circ$ & 0 & 0 & 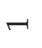 & 0 \\
\hline мәлри $\forall$ IS & 0 & 0 & 0 & 0 & 0 & 0 & 0 & 0 & 0 & 0 & 0 & 0 & 0 & $r$ & 0 & 0 & 0 & 0 & - & 0 & 0 \\
\hline 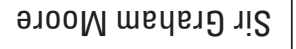 & 0 & 0 & 0 & 0 & 0 & 0 & 0 & 0 & 0 & $\circ$ & 0 & 0 & 0 & $\circ$ & 0 & 0 & 0 & 0 & 0 & 0 & 0 \\
\hline ешәㅇN MN & 0 & 0 & $\neg$ & 0 & 0 & 0 & 0 & 0 & 0 & 0 & 0 & 0 & 0 & 0 & 0 & 0 & 0 & 0 & 0 & 0 & D \\
\hline uлoqso әрpp!W & 0 & 0 & 0 & 0 & 0 & 0 & 0 & 0 & 0 & 0 & 0 & 0 & 0 & 0 & 0 & 0 & 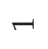 & 0 & 0 & 0 & 0 \\
\hline Nıew & 0 & 0 & 0 & 0 & 0 & 0 & 0 & 0 & 0 & 0 & 0 & 0 & 0 & 0 & 0 & 0 & 0 & 0 & 0 & 0 & 0 \\
\hline 6u0ך & 0 & 0 & 0 & 0 & 0 & 0 & 0 & 0 & 0 & 0 & 0 & 0 & 0 & 0 & 0 & 0 & 0 & 0 & 0 & 0 & 0 \\
\hline ие|чэеך & 0 & 0 & 0 & 0 & 0 & 0 & 0 & 0 & 0 & 0 & 0 & 0 & 0 & 0 & 0 & 0 & 0 & 0 & 0 & 0 & b \\
\hline 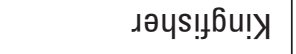 & 0 & $\neg$ & 0 & 0 & 0 & 0 & 0 & 0 & 0 & 0 & 0 & 0 & 0 & 0 & 0 & 0 & 0 & 0 & 0 & 0 & b \\
\hline sıәાе) & $\neg$ & 0 & 0 & 0 & 0 & 0 & 0 & 0 & 0 & 0 & 0 & $\neg$ & 0 & 0 & 0 & 0 & 0 & 0 & 0 & 0 & \\
\hline uәрр!н & 0 & 0 & 0 & 0 & 0 & 0 & 0 & 0 & 0 & 0 & 0 & 0 & 0 & 0 & 0 & 0 & 0 & 0 & 0 & 0 & \\
\hline nınbune & 0 & 0 & 0 & 0 & 0 & 0 & 0 & 0 & 0 & 0 & 0 & 0 & 0 & 0 & 0 & 0 & 0 & 0 & 0 & 0 & b \\
\hline иo!̣euoג0ว & 0 & 0 & 0 & 0 & 0 & 0 & 0 & 0 & 0 & 0 & 0 & 0 & 0 & 0 & 0 & 0 & 0 & 0 & 0 & 0 & D \\
\hline u!ฺеw meরg & 0 & 0 & 0 & 0 & 0 & 0 & 0 & 0 & 0 & 0 & 0 & 0 & 0 & 0 & 0 & 0 & 0 & 0 & 0 & 0 & 0 \\
\hline әәлебиоog & 0 & 0 & 0 & 0 & $\neg$ & 0 & 0 & 0 & 0 & $\neg$ & 0 & 0 & 0 & 0 & $\neg$ & 0 & 0 & $\neg$ & 0 & 0 & 0 \\
\hline ә66!g & - & 0 & 0 & 0 & 0 & 0 & 0 & $r$ & 0 & 0 & 0 & 0 & $\neg$ & 0 & 0 & 0 & 0 & 0 & 0 & 0 & 0 \\
\hline snısn6n $\forall$ & 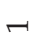 & 0 & 0 & $\neg$ & 0 & 0 & $\neg$ & 0 & 0 & 0 & 0 & 0 & 0 & 0 & 0 & 0 & 0 & 0 & 0 & 0 & 0 \\
\hline snyd|op & 0 & 0 & 0 & 0 & 0 & 0 & 0 & 0 & $\neg$ & 0 & 0 & 0 & 0 & 0 & 0 & 0 & 0 & 0 & 0 & 0 & 0 \\
\hline $\begin{array}{l}\text { 음 } \\
\text { 음 }\end{array}$ & 我 & 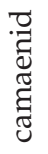 & 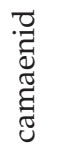 & 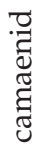 & 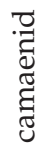 & 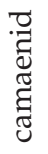 & 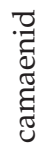 & 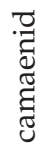 & 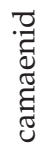 & 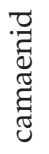 & 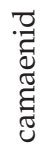 & 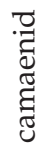 & 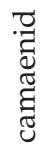 & 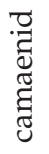 & 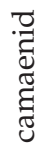 & 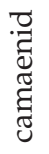 & 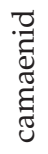 & 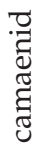 & 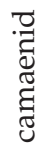 & 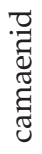 & 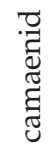 \\
\hline
\end{tabular}

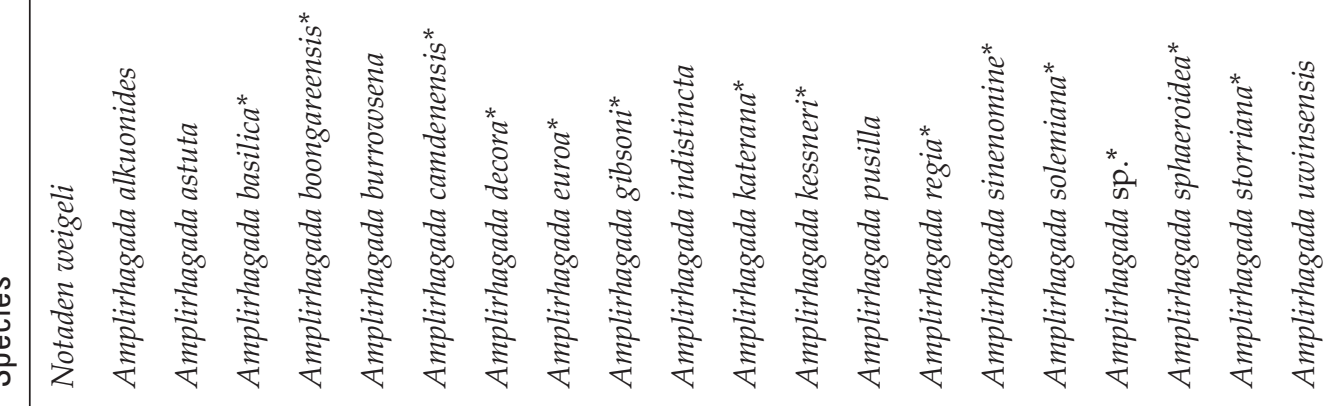




\begin{tabular}{|c|c|c|c|c|c|c|c|c|c|c|c|c|c|c|c|c|c|c|c|c|c|}
\hline meןeןnM & 0 & 0 & 0 & 0 & 0 & 0 & 0 & 0 & 0 & 0 & 0 & 0 & 0 & 0 & 0 & 0 & 0 & 0 & 0 & 0 & 0 \\
\hline Inблем |пблем & 0 & 0 & 0 & ○ & 0 & 0 & 0 & 0 & ○ & 0 & 0 & 0 & 0 & 0 & 0 & 0 & 0 & 0 & 0 & 0 & 0 \\
\hline su!m n & ○ & 0 & 0 & 0 & 0 & 0 & 0 & 0 & 0 & 0 & $\circ$ & 0 & 0 & 0 & $\neg$ & 0 & 0 & 0 & 0 & 0 & 0 \\
\hline рәшеu-un & 0 & 0 & 0 & 0 & 0 & 0 & 0 & 0 & 0 & 0 & $\circ$ & 0 & 0 & $\circ$ & 0 & 0 & $\neg$ & 0 & 0 & 0 & 0 \\
\hline uıoqso lsəM yłnos & 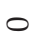 & 0 & 0 & 0 & 0 & 0 & 0 & 0 & 0 & 0 & $\neg$ & 0 & 0 & 0 & 0 & 0 & 0 & 0 & 0 & 0 & ○ \\
\hline Nepuns & ○ & 0 & 0 & 0 & 0 & 0 & 0 & 0 & 0 & 0 & 0 & 0 & 0 & 0 & 0 & 0 & 0 & 0 & 0 & 0 & ○ \\
\hline גנOוS & 0 & 0 & 0 & 0 & 0 & 0 & 0 & 0 & 0 & 0 & 0 & 0 & 0 & 0 & 0 & 0 & $\vdash$ & 0 & 0 & 0 & ○ \\
\hline мәлри $\forall$ IS & 0 & 0 & 0 & 0 & 0 & 0 & 0 & 0 & 0 & 0 & 0 & 0 & 0 & 0 & 0 & 0 & 0 & 0 & 0 & 0 & 0 \\
\hline & 0 & 0 & 0 & 0 & 0 & 0 & 0 & 0 & 0 & 0 & 0 & 0 & $\circ$ & 0 & 0 & 0 & 0 & 0 & 0 & 0 & 0 \\
\hline ешәㅇN MN & 0 & 0 & 0 & 0 & 0 & 0 & 0 & 0 & 0 & 0 & 0 & 0 & 0 & 0 & 0 & 0 & 0 & 0 & 0 & 0 & 0 \\
\hline uıoqso әрp!W & 0 & 0 & 0 & 0 & 0 & 0 & 0 & 0 & 0 & - & 0 & 0 & 0 & 0 & 0 & 0 & 0 & 0 & 0 & $\neg$ & 0 \\
\hline Nıew & 0 & 0 & 0 & 0 & 0 & 0 & 0 & 0 & 0 & 0 & 0 & 0 & 0 & 0 & 0 & 0 & 0 & 0 & 0 & 0 & 0 \\
\hline 6u0ך & 0 & 0 & 0 & 0 & 0 & 0 & 0 & 0 & 0 & 0 & 0 & 0 & 0 & 0 & 0 & 0 & 0 & 0 & 0 & 0 & 0 \\
\hline ие|чэеך & 0 & 0 & 0 & 0 & 0 & 0 & 0 & 0 & 0 & 0 & 0 & 0 & 0 & 0 & 0 & 0 & 0 & 0 & 0 & 0 & 0 \\
\hline 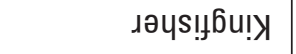 & 0 & 0 & 0 & 0 & 0 & 0 & 0 & 0 & 0 & 0 & 0 & 0 & 0 & 0 & 0 & 0 & 0 & 0 & 0 & 0 & 0 \\
\hline sıәte્ર & 0 & 0 & 0 & 0 & 0 & 0 & 0 & 0 & 0 & 0 & 0 & $\neg$ & 0 & 0 & 0 & 0 & 0 & 0 & 0 & 0 & 0 \\
\hline uәрр!н & 0 & 0 & 0 & 0 & 0 & 0 & 0 & 0 & 0 & 0 & 0 & 0 & 0 & 0 & 0 & 0 & 0 & 0 & 0 & 0 & 0 \\
\hline nınbune & 0 & 0 & - & 0 & 0 & $\neg$ & 0 & 0 & 0 & 0 & 0 & 0 & 0 & 0 & 0 & $\neg$ & 0 & 0 & 0 & 0 & 0 \\
\hline uo!ฺeuodoว & $\neg$ & 0 & 0 & $\neg$ & 0 & 0 & 0 & 0 & $\neg$ & 0 & 0 & 0 & 0 & 0 & 0 & 0 & 0 & - & 0 & 0 & 0 \\
\hline u!ıew meরg & 0 & 0 & 0 & 0 & 0 & 0 & 0 & 0 & 0 & 0 & 0 & 0 & 0 & 0 & 0 & 0 & 0 & 0 & 0 & 0 & 0 \\
\hline әәлебиоog & 0 & 0 & 0 & 0 & $\neg$ & 0 & 0 & 0 & 0 & 0 & 0 & 0 & $\neg$ & 0 & 0 & 0 & 0 & 0 & 0 & 0 & $\neg$ \\
\hline ә66!g & 0 & 0 & 0 & 0 & 0 & 0 & 0 & $\neg$ & 0 & 0 & 0 & 0 & 0 & - & 0 & 0 & 0 & 0 & $\neg$ & 0 & 0 \\
\hline snısn6n & 0 & 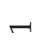 & 0 & 0 & 0 & 0 & $\neg$ & 0 & 0 & 0 & 0 & 0 & 0 & 0 & 0 & $r$ & 0 & 0 & 0 & 0 & 0 \\
\hline snyd|op $\forall$ & 0 & 0 & 0 & 0 & 0 & 0 & 0 & 0 & 0 & 0 & 0 & 0 & 0 & 0 & 0 & 0 & 0 & 0 & 0 & 0 & 0 \\
\hline $\begin{array}{l}\text { 음 } \\
\text { 늠 }\end{array}$ & 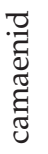 & 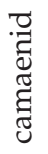 & 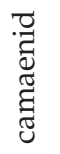 & 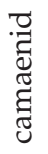 & 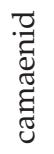 & 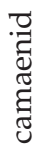 & 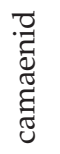 & 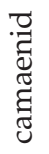 & 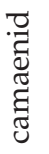 & 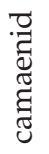 & 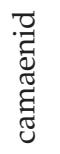 & 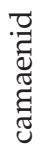 & 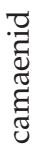 & 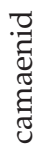 & 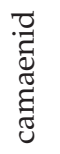 & 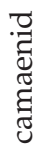 & 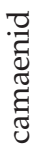 & 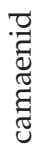 & 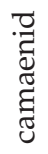 & 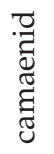 & 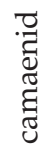 \\
\hline
\end{tabular}

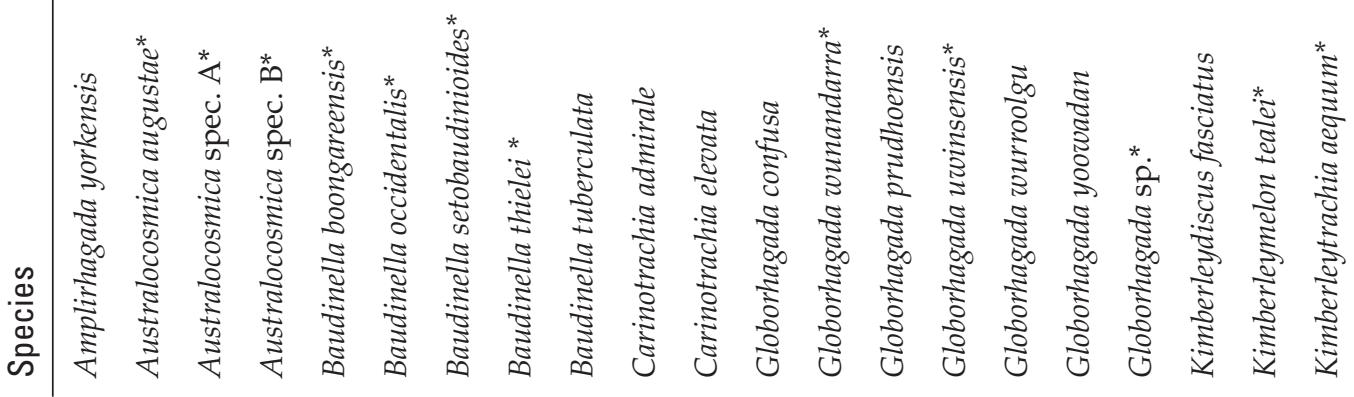




\begin{tabular}{|c|c|c|c|c|c|c|c|c|c|c|c|c|c|c|c|c|c|c|c|c|c|}
\hline meןeןnM & 0 & 0 & 0 & 0 & 0 & 0 & 0 & 0 & 0 & 0 & 0 & $\neg$ & 0 & 0 & 0 & 0 & 0 & 0 & 0 & 0 & 0 \\
\hline Inблем |пблем & 0 & 0 & 0 & ○ & 0 & 0 & 0 & 0 & ○ & 0 & 0 & 0 & 0 & 0 & 0 & 0 & 0 & 0 & 0 & 0 & 0 \\
\hline su!m n & ○ & 0 & 0 & 0 & $\neg$ & 0 & 0 & 0 & 0 & 0 & $\circ$ & 0 & 0 & 0 & $\neg$ & 0 & 0 & 0 & 0 & 0 & o \\
\hline рәшеu-un & 0 & 0 & 0 & 0 & 0 & 0 & 0 & 0 & 0 & 0 & $\circ$ & 0 & 0 & $\circ$ & 0 & 0 & 0 & 0 & 0 & 0 & ○ \\
\hline uıoqso lsəM yłnos & 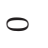 & 0 & 0 & 0 & 0 & 0 & 0 & 0 & 0 & 0 & 0 & 0 & 0 & 0 & 0 & 0 & 0 & 0 & 0 & 0 & ○ \\
\hline Nepuns & ○ & 0 & 0 & 0 & 0 & 0 & 0 & 0 & 0 & 0 & 0 & 0 & 0 & 0 & 0 & 0 & - & $\neg$ & 0 & 0 & 0 \\
\hline גנOוS & 0 & 0 & 0 & 0 & 0 & $\neg$ & 0 & 0 & 0 & 0 & 0 & 0 & 0 & 0 & 0 & 0 & 0 & 0 & - & 0 & 0 \\
\hline мәлри $\forall$ IS & 0 & 0 & 0 & 0 & 0 & 0 & 0 & 0 & 0 & 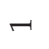 & 0 & 0 & 0 & 0 & 0 & 0 & 0 & 0 & 0 & 0 & 0 \\
\hline & 0 & 0 & 0 & 0 & 0 & 0 & 0 & 0 & 0 & 0 & 0 & 0 & $\circ$ & 0 & 0 & 0 & 0 & 0 & 0 & 0 & 0 \\
\hline ешәㅇN MN & 0 & 0 & 0 & 0 & 0 & 0 & 0 & 0 & 0 & 0 & 0 & 0 & $\neg$ & 0 & 0 & 0 & 0 & 0 & 0 & 0 & 0 \\
\hline uлoqso әрpp!W & 0 & 0 & 0 & 0 & 0 & 0 & 0 & 0 & 0 & 0 & 0 & 0 & 0 & 0 & 0 & 0 & 0 & 0 & 0 & 0 & 0 \\
\hline Nıew & 0 & 0 & 0 & 0 & 0 & 0 & 0 & 0 & 0 & 0 & 0 & 0 & 0 & 0 & 0 & 0 & 0 & 0 & 0 & 0 & 0 \\
\hline 6u0ך & 0 & 0 & 0 & 0 & 0 & 0 & 0 & 0 & 0 & 0 & 0 & 0 & 0 & 0 & 0 & 0 & 0 & 0 & 0 & 0 & - \\
\hline ие|чэеך & 0 & 0 & 0 & 0 & 0 & 0 & 0 & 0 & $\neg$ & 0 & 0 & 0 & 0 & 0 & 0 & 0 & 0 & 0 & 0 & 0 & 0 \\
\hline 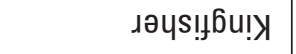 & 0 & 0 & 0 & 0 & 0 & 0 & 0 & 0 & 0 & 0 & 0 & 0 & 0 & 0 & 0 & 0 & 0 & 0 & 0 & 0 & b \\
\hline sıәte્ર & 0 & 0 & 0 & 0 & 0 & 0 & 0 & 0 & 0 & 0 & 0 & 0 & 0 & 0 & 0 & 0 & 0 & 0 & 0 & 0 & $D$ \\
\hline uәрр!н & 0 & 0 & 0 & 0 & 0 & 0 & 0 & 0 & 0 & 0 & 0 & 0 & 0 & 0 & 0 & 0 & $\neg$ & 0 & 0 & 0 & 0 \\
\hline nınbune & 0 & 0 & 0 & 0 & 0 & 0 & $\neg$ & 0 & 0 & 0 & 0 & 0 & 0 & 0 & 0 & 0 & 0 & 0 & 0 & 0 & b \\
\hline uo!ฺeuodoว & 0 & 0 & 0 & 0 & 0 & 0 & 0 & 0 & 0 & 0 & - & 0 & 0 & 0 & 0 & 0 & 0 & 0 & 0 & 0 & 0 \\
\hline u!ıew meরg & 0 & 0 & 0 & 0 & 0 & 0 & 0 & 0 & 0 & 0 & 0 & 0 & 0 & 0 & 0 & 0 & 0 & 0 & 0 & 0 & 0 \\
\hline әәлебиоog & $\neg$ & 0 & 0 & $r$ & 0 & 0 & 0 & 0 & 0 & 0 & 0 & 0 & 0 & $\neg$ & 0 & 0 & 0 & 0 & 0 & 0 & 0 \\
\hline ә66!g & 0 & 0 & 0 & 0 & 0 & 0 & 0 & $\neg$ & 0 & 0 & 0 & 0 & 0 & 0 & 0 & $r$ & 0 & 0 & 0 & 0 & 0 \\
\hline snısn6n & 0 & 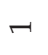 & $r$ & 0 & 0 & 0 & 0 & 0 & 0 & 0 & 0 & 0 & 0 & 0 & 0 & 0 & 0 & 0 & 0 & $\neg$ & 0 \\
\hline snyd|op $\forall$ & 0 & 0 & 0 & 0 & 0 & 0 & 0 & 0 & 0 & 0 & 0 & 0 & 0 & 0 & 0 & 0 & 0 & 0 & 0 & 0 & 0 \\
\hline $\begin{array}{l}\text { 음 } \\
\text { 늠 }\end{array}$ & 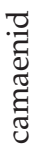 & 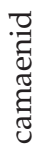 & 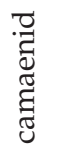 & 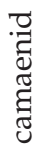 & 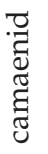 & 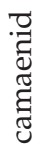 & 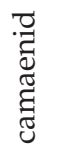 & 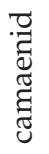 & 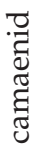 & 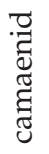 & 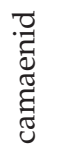 & 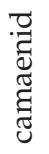 & 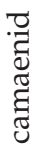 & 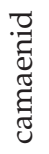 & 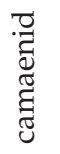 & 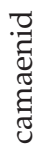 & 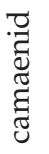 & 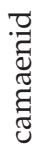 & 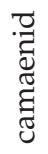 & 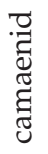 & 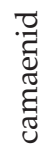 \\
\hline
\end{tabular}

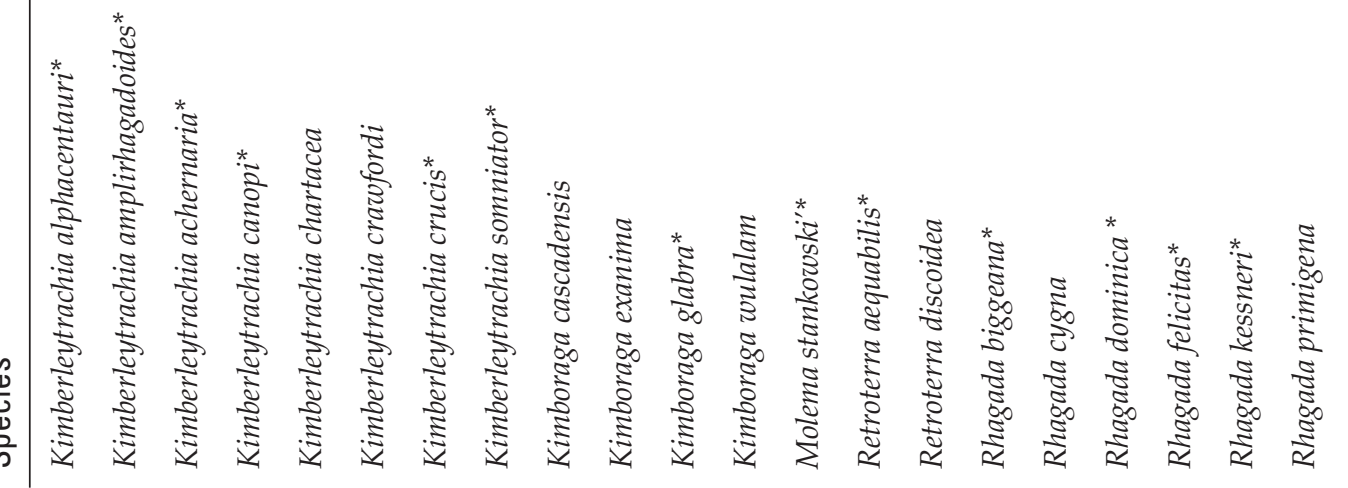




\begin{tabular}{|c|c|c|c|c|c|c|c|c|c|c|c|c|c|c|c|c|c|c|c|c|c|}
\hline meןeןnM & 0 & 0 & 0 & 0 & 0 & - & 0 & 0 & 0 & 0 & 0 & 0 & 0 & 0 & 0 & 0 & 0 & 0 & 0 & 0 & 0 \\
\hline Inблем |пблем & 0 & 0 & 0 & ○ & 0 & 0 & 0 & 0 & ○ & $\neg$ & 0 & 0 & 0 & 0 & 0 & 0 & 0 & 0 & 0 & 0 & 0 \\
\hline su!m n & ○ & 0 & 0 & 0 & 0 & 0 & 0 & 0 & 0 & 0 & $\circ$ & 0 & 0 & 0 & 0 & 0 & 0 & 0 & 0 & 0 & o \\
\hline рәшеu-un & 0 & 0 & 0 & 0 & 0 & 0 & 0 & 0 & 0 & $\circ$ & $\circ$ & 0 & 0 & $\circ$ & 0 & 0 & 0 & 0 & 0 & 0 & ○ \\
\hline uıoqso lsəM yłnos & 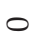 & 0 & 0 & 0 & 0 & 0 & 0 & 0 & 0 & 0 & $\neg$ & 0 & 0 & 0 & 0 & 0 & 0 & 0 & 0 & 0 & ○ \\
\hline Nepuns & ○ & 0 & 0 & 0 & 0 & 0 & 0 & 0 & 0 & 0 & 0 & 0 & 0 & 0 & 0 & 0 & 0 & 0 & 0 & 0 & 0 \\
\hline גנOוS & 0 & 0 & 0 & 0 & 0 & 0 & 0 & 0 & $\neg$ & 0 & 0 & 0 & 0 & 0 & 0 & 0 & 0 & 0 & 0 & 0 & 0 \\
\hline мәлри $\forall$ IS & 0 & 0 & 0 & 0 & $\neg$ & 0 & 0 & 0 & 0 & 0 & 0 & 0 & 0 & 0 & 0 & 0 & 0 & 0 & 0 & 0 & 0 \\
\hline & 0 & 0 & 0 & 0 & 0 & 0 & 0 & 0 & 0 & 0 & 0 & 0 & $\circ$ & 0 & $\neg$ & 0 & 0 & 0 & 0 & 0 & 0 \\
\hline ешәㅇN MN & 0 & 0 & 0 & 0 & 0 & 0 & $\neg$ & 0 & 0 & 0 & 0 & 0 & 0 & 0 & 0 & 0 & 0 & 0 & 0 & 0 & - \\
\hline uıoqso әрp!W & 0 & 0 & 0 & 0 & 0 & 0 & 0 & $\neg$ & 0 & 0 & - & 0 & 0 & 0 & 0 & 0 & 0 & 0 & 0 & 0 & 0 \\
\hline Nıew & 0 & 0 & 0 & 0 & 0 & 0 & 0 & 0 & 0 & 0 & 0 & 0 & 0 & 0 & 0 & 0 & 0 & 0 & 0 & 0 & 0 \\
\hline 6u07 & 0 & 0 & 0 & 0 & 0 & 0 & 0 & 0 & 0 & 0 & 0 & 0 & 0 & 0 & 0 & 0 & 0 & 0 & 0 & 0 & 0 \\
\hline ие|чэеך & 0 & 0 & 0 & 0 & 0 & 0 & 0 & 0 & 0 & 0 & 0 & 0 & 0 & 0 & 0 & 0 & 0 & 0 & 0 & 0 & 0 \\
\hline 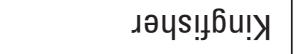 & 0 & 0 & 0 & 0 & 0 & 0 & 0 & 0 & 0 & 0 & 0 & 0 & 0 & 0 & 0 & 0 & $\neg$ & 0 & 0 & 0 & b \\
\hline sıәte્ર & 0 & 0 & 0 & 0 & 0 & 0 & 0 & 0 & 0 & 0 & 0 & 0 & 0 & 0 & 0 & 0 & 0 & 0 & 0 & 0 & $D$ \\
\hline uәрр!н & 0 & 0 & 0 & 0 & 0 & 0 & 0 & 0 & 0 & 0 & 0 & 0 & 0 & 0 & 0 & 0 & 0 & 0 & 0 & $\neg$ & 0 \\
\hline nınbune & 0 & 0 & 0 & 0 & 0 & 0 & 0 & 0 & 0 & 0 & 0 & 0 & 0 & 0 & 0 & 0 & 0 & 0 & -1 & 0 & b \\
\hline uo!̣euodoכ & 0 & 0 & 0 & $\neg$ & 0 & 0 & 0 & 0 & 0 & 0 & 0 & 0 & 0 & 0 & 0 & 0 & 0 & 0 & 0 & 0 & 0 \\
\hline u!uew mekg & $\neg$ & - & 0 & 0 & 0 & 0 & 0 & 0 & 0 & 0 & 0 & 0 & 0 & 0 & 0 & 0 & 0 & 0 & 0 & 0 & 0 \\
\hline әәлебиоog & 0 & 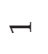 & - & 0 & 0 & 0 & 0 & 0 & 0 & 0 & 0 & 0 & 0 & 0 & 0 & $\neg$ & 0 & 0 & 0 & 0 & 0 \\
\hline ә66!g & 0 & 0 & 0 & 0 & 0 & 0 & 0 & 0 & 0 & 0 & 0 & 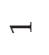 & 0 & 0 & 0 & 0 & 0 & 0 & 0 & 0 & 0 \\
\hline snısn6n & 0 & 0 & 0 & 0 & 0 & 0 & 0 & 0 & 0 & 0 & 0 & 0 & $\neg$ & $r$ & 0 & 0 & 0 & $\neg$ & 0 & 0 & 0 \\
\hline snyd|op $\forall$ & 0 & 0 & 0 & 0 & 0 & 0 & 0 & 0 & 0 & 0 & 0 & 0 & 0 & 0 & 0 & 0 & 0 & 0 & 0 & 0 & 0 \\
\hline $\begin{array}{l}\text { 음 } \\
\text { 늠 }\end{array}$ & 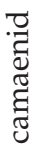 & 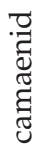 & 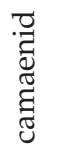 & 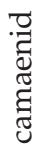 & 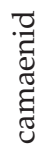 & 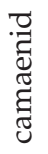 & 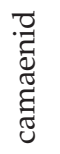 & 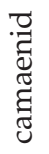 & 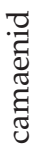 & 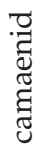 & 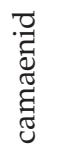 & 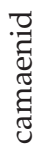 & 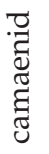 & 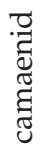 & 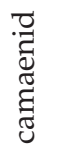 & 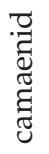 & 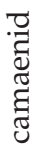 & 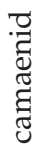 & 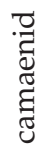 & 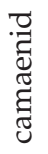 & 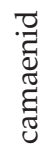 \\
\hline
\end{tabular}

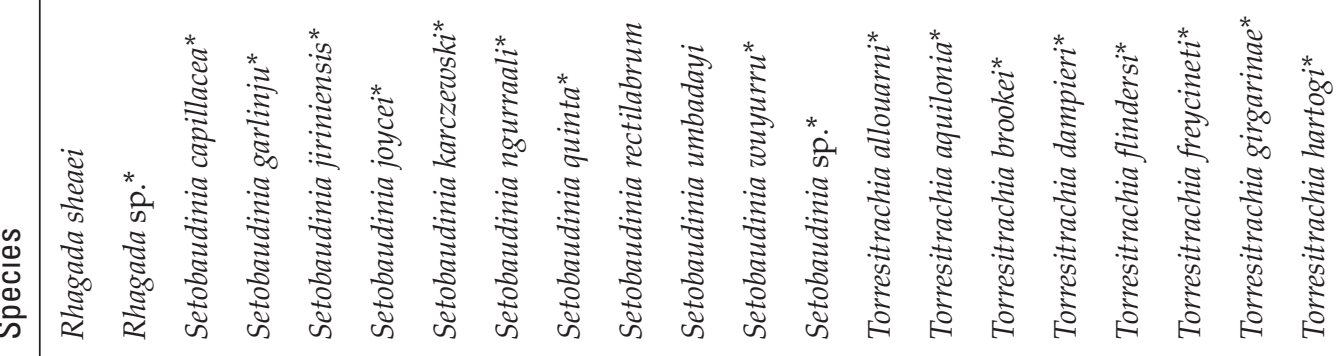




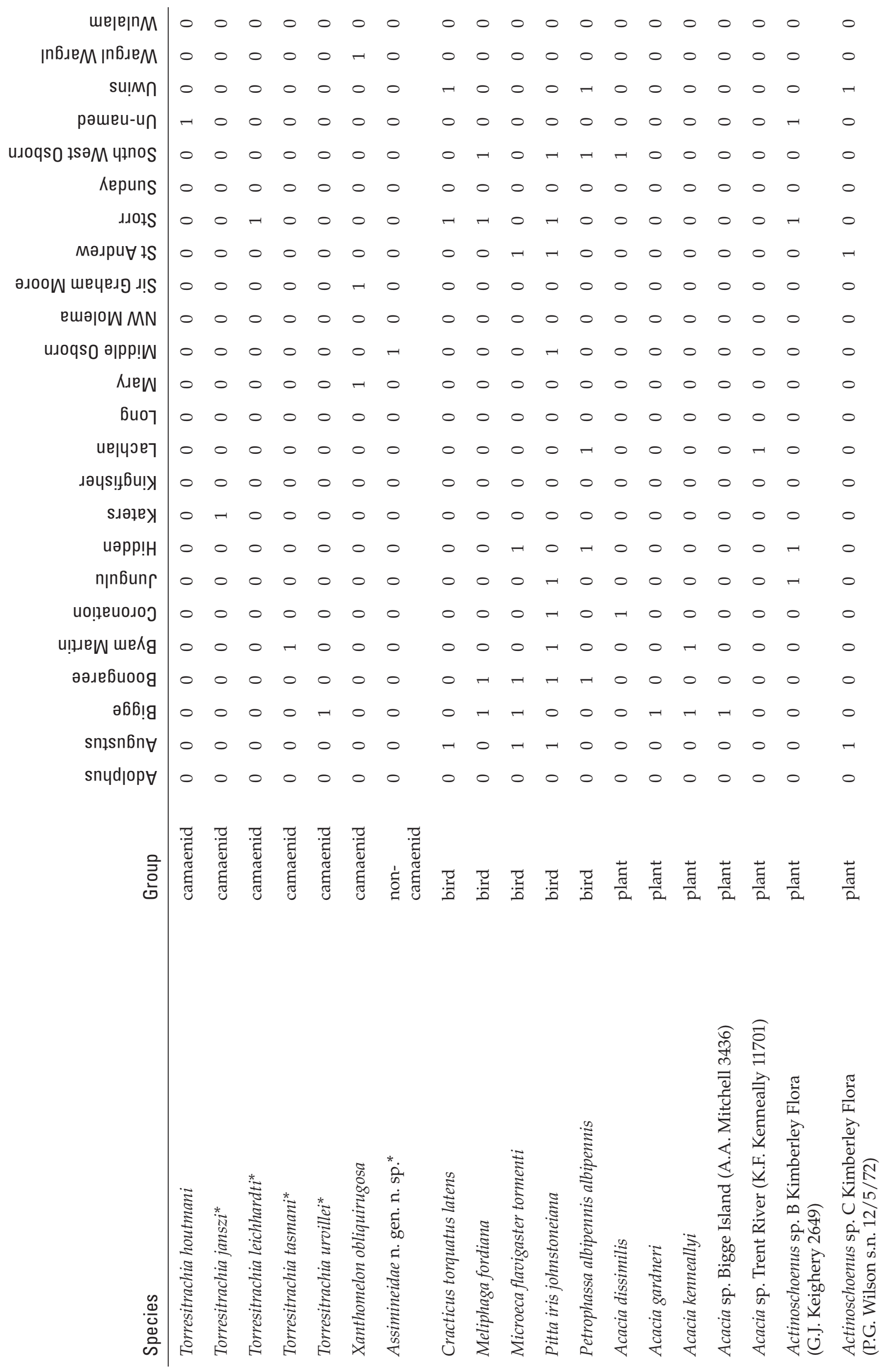




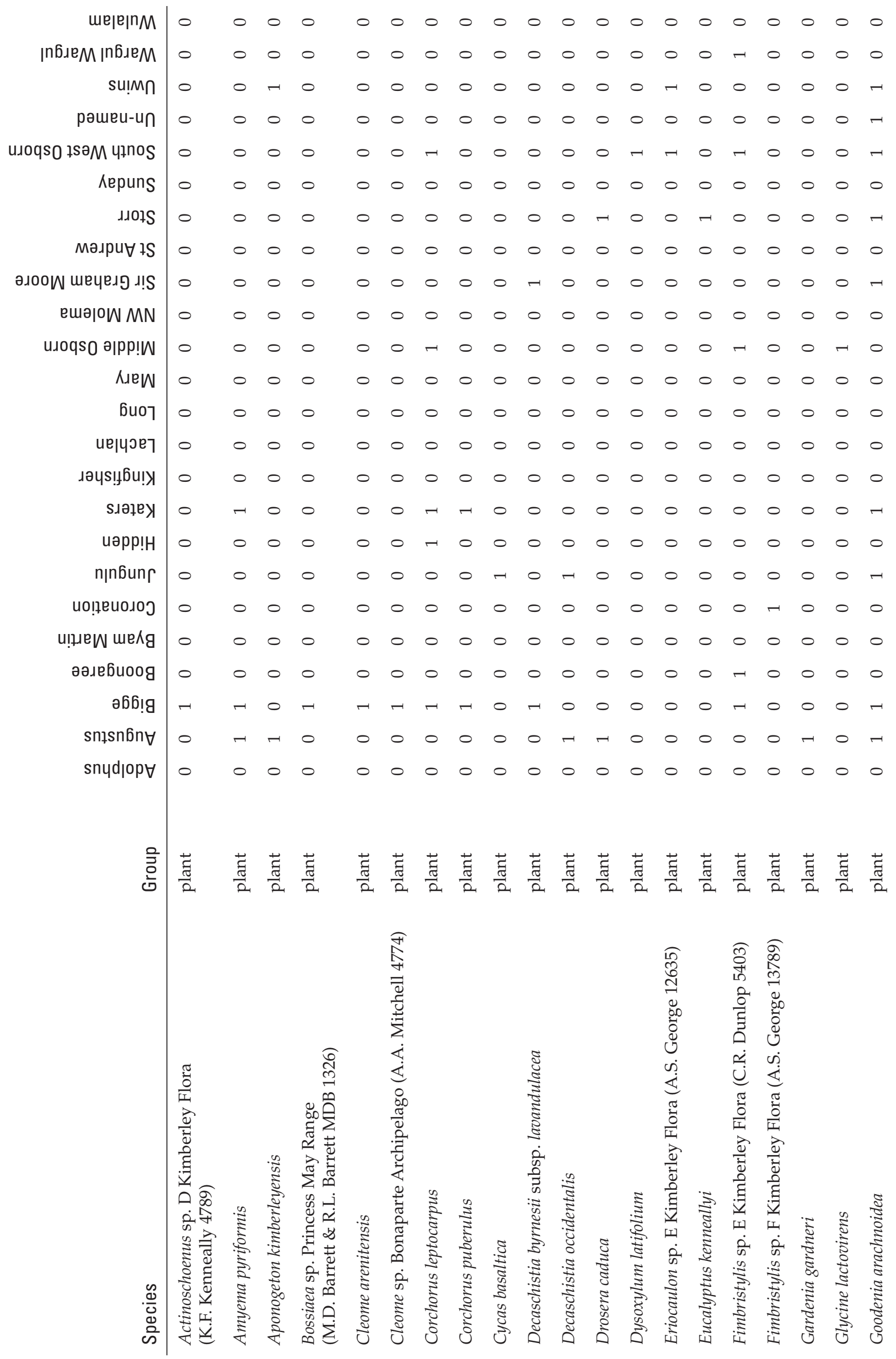




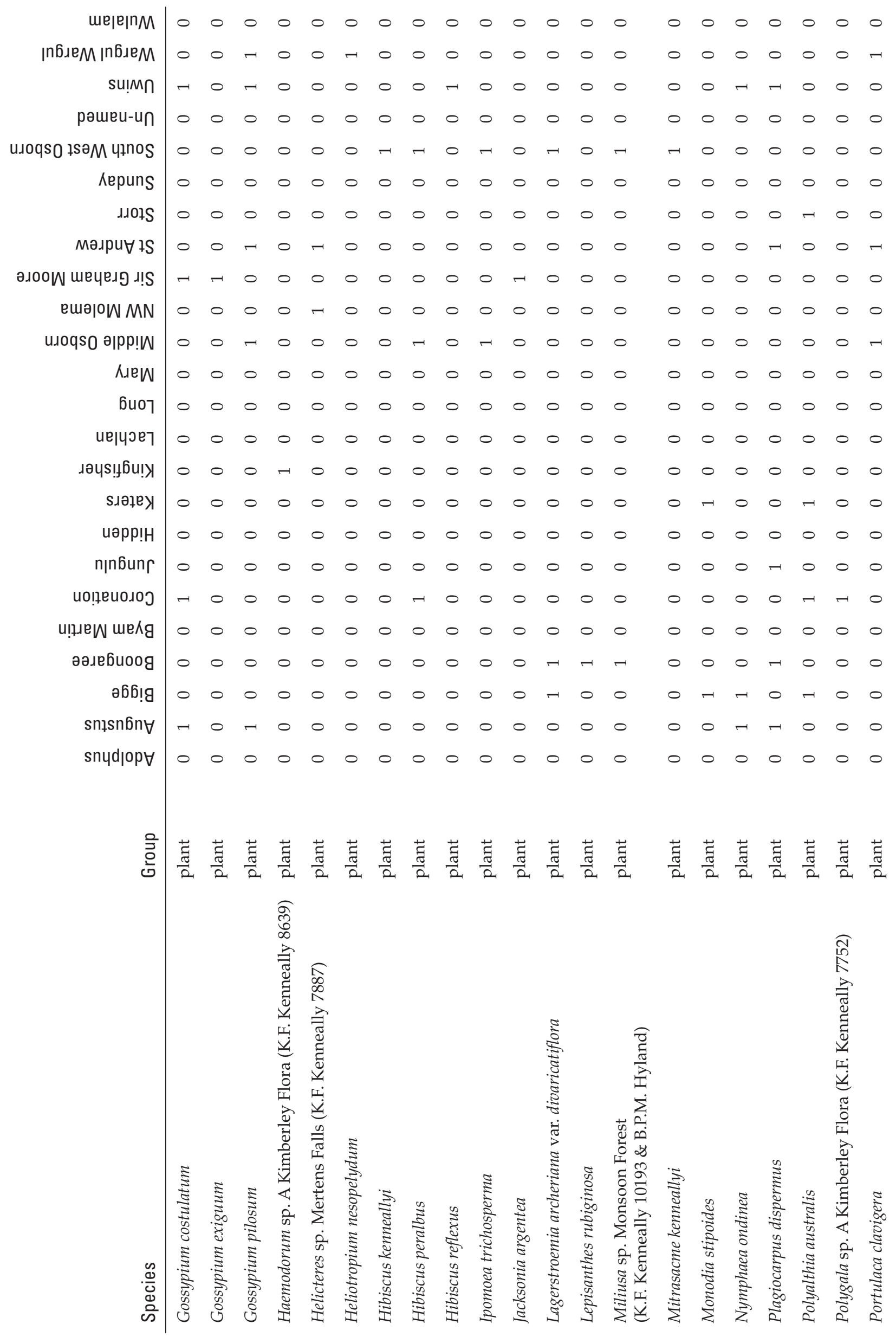




\begin{tabular}{|c|c|c|c|c|c|c|c|c|c|c|c|c|c|c|c|c|}
\hline шеје|пм & 0 & 0 & 0 & 0 & 0 & 0 & 0 & 0 & 0 & 0 & 0 & 0 & 0 & 0 & 0 & 0 \\
\hline ןпьем |пблем & 0 & 0 & 0 & 0 & 0 & 0 & 0 & 0 & 0 & 0 & 0 & 0 & 0 & 0 & 0 & $\circ$ \\
\hline su!m n & 0 & 0 & 0 & 0 & 0 & 0 & - & 0 & 0 & 0 & 0 & 0 & 0 & 0 & 0 & 0 \\
\hline рәшеи-un & 0 & 0 & 0 & 0 & 0 & 0 & 0 & 0 & 0 & 0 & 0 & 0 & 0 & 0 & 0 & 0 \\
\hline uıoqso łsəM чłnos & 0 & 0 & 0 & 0 & $\neg$ & 0 & 0 & 0 & 0 & 0 & $\neg$ & 0 & 0 & 0 & 0 & $\neg$ \\
\hline Nepuns & 0 & 0 & 0 & 0 & 0 & 0 & 0 & 0 & 0 & 0 & 0 & 0 & 0 & 0 & 0 & 0 \\
\hline גנOIS & 0 & 0 & 0 & 0 & 0 & 0 & 0 & - & 0 & 0 & 0 & 0 & 0 & 0 & 0 & $\circ$ \\
\hline мәлриҰ IS & 0 & 0 & 0 & 0 & 0 & 0 & 0 & 0 & 0 & 0 & 0 & 0 & 0 & 0 & 0 & 0 \\
\hline פוג פגיג & 0 & 0 & 0 & 0 & 0 & $r$ & 0 & 0 & 0 & 0 & 0 & - & 0 & 0 & 0 & 0 \\
\hline ешәㅇN MN & 0 & 0 & 0 & 0 & 0 & 0 & 0 & 0 & 0 & 0 & 0 & 0 & 0 & 0 & 0 & 0 \\
\hline uıoqso әррp!W & 0 & 0 & - & 0 & 0 & 0 & 0 & 0 & 0 & 0 & 0 & 0 & 0 & 0 & 0 & 0 \\
\hline Nıew & 0 & - & 0 & 0 & 0 & 0 & 0 & 0 & 0 & 0 & 0 & - & 0 & 0 & 0 & 0 \\
\hline 6uoך & 0 & 0 & 0 & 0 & 0 & 0 & 0 & 0 & 0 & 0 & 0 & 0 & 0 & 0 & 0 & 0 \\
\hline иерчэеך & 0 & 0 & 0 & 0 & 0 & 0 & 0 & 0 & 0 & 0 & 0 & 0 & 0 & 0 & 0 & 0 \\
\hline дәчs!̣bu!ऐ & 0 & 0 & 0 & 0 & 0 & 0 & 0 & 0 & 0 & 0 & 0 & 0 & 0 & 0 & 0 & 0 \\
\hline sıәte્ર & 0 & 0 & 0 & 0 & 0 & 0 & 0 & 0 & 0 & 0 & 0 & 0 & 0 & 0 & 0 & 0 \\
\hline uәрр!н & 0 & 0 & 0 & 0 & 0 & 0 & 0 & 0 & 0 & 0 & 0 & 0 & 0 & 0 & 0 & 0 \\
\hline nןnbune & 0 & 0 & 0 & 0 & 0 & 0 & - & - & 0 & 0 & 0 & 0 & 0 & 0 & 0 & 0 \\
\hline uo!̣euodoכ & 0 & 0 & 0 & 0 & 0 & 0 & $\neg$ & 0 & 0 & 0 & 0 & - & 0 & 0 & 0 & 0 \\
\hline u!גew meরg & 0 & 0 & -1 & 0 & 0 & 0 & 0 & - & 0 & $r$ & 0 & 0 & 0 & 0 & 0 & 0 \\
\hline әәлебиоog & $\neg$ & 0 & 0 & 0 & 0 & 0 & 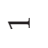 & $\neg$ & 0 & 0 & $\neg$ & 0 & 0 & 0 & 0 & 0 \\
\hline әб6!g & 0 & 0 & 0 & $\neg$ & 0 & 0 & - & 0 & - & 0 & 0 & 0 & - & 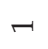 & 0 & 0 \\
\hline snısn6n $\forall$ & 0 & 0 & $\neg$ & 0 & 0 & 0 & $\neg$ & - & 0 & 0 & 0 & 0 & 0 & 0 & 0 & 0 \\
\hline snydןop & 0 & 0 & 0 & 0 & 0 & 0 & 0 & 0 & 0 & 0 & 0 & 0 & 0 & 0 & 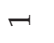 & 0 \\
\hline $\begin{array}{l}\text { 음 } \\
\text { 는 }\end{array}$ & $\frac{\overrightarrow{\mathbb{Z}}}{2}$ & $\frac{\vec{a}}{\stackrel{\vec{J}}{2}}$ & $\frac{\vec{J}}{\stackrel{\vec{J}}{2}}$ & 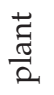 & $\begin{array}{l}\overrightarrow{\vec{J}} \\
\frac{\vec{L}}{2}\end{array}$ & $\begin{array}{l}\overrightarrow{\vec{J}} \\
\frac{\vec{a}}{2}\end{array}$ & 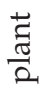 & $\frac{\vec{\pi}}{2}$ & $\begin{array}{l}\overrightarrow{\tilde{a}} \\
\frac{\vec{a}}{2}\end{array}$ & $\frac{\vec{a}}{\vec{a}}$ & $\frac{\vec{z}}{2}$ & $\begin{array}{l}\overrightarrow{\vec{J}} \\
\frac{\pi}{2}\end{array}$ & $\begin{array}{l}\underset{\vec{J}}{2} \\
\stackrel{2}{2}\end{array}$ & $\frac{\vec{a}}{\stackrel{\vec{a}}{2}}$ & $\begin{array}{l}\overrightarrow{\vec{J}} \\
\frac{1}{2}\end{array}$ & $\begin{array}{l}\overrightarrow{\vec{Z}} \\
\frac{\vec{J}}{2}\end{array}$ \\
\hline $\begin{array}{l}\mathscr{d} \\
\frac{d}{0} \\
\text { के }\end{array}$ & 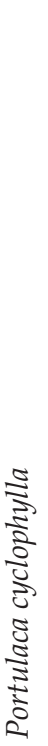 & 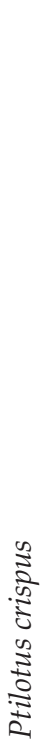 & 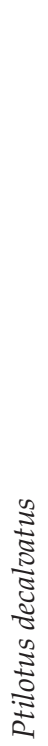 & 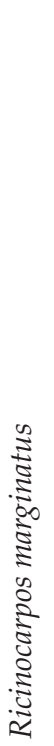 & 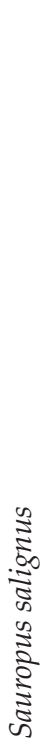 & 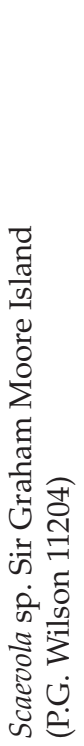 & 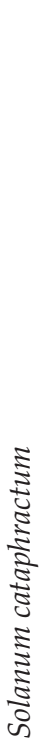 & 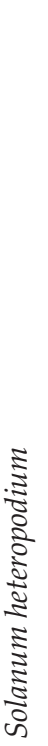 & 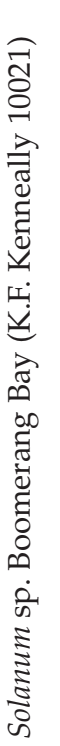 & 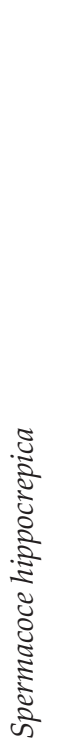 & 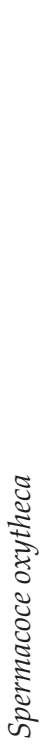 & 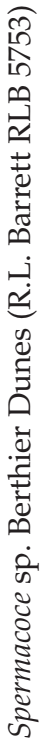 & 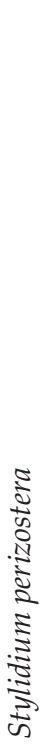 & 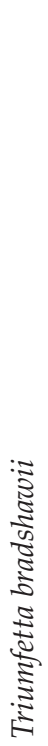 & 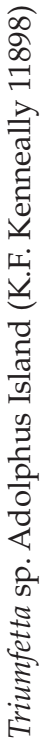 & 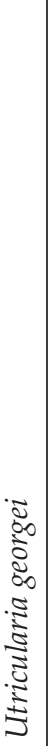 \\
\hline
\end{tabular}


APPENDIX 4 Number of known surveys on the 24 Kimberley islands sampled including the Kimberley Island Biological Survey for birds, reptiles, non-volant (nv) mammals and bats.

\begin{tabular}{|c|c|c|c|c|}
\hline & birds & reptiles & nv mammals & bats \\
\hline Adolphus & 3 & 1 & 1 & 1 \\
\hline Augustus & 3 & 4 & 4 & 4 \\
\hline Bigge & 6 & 5 & 5 & 2 \\
\hline Boongaree & 3 & 5 & 5 & 5 \\
\hline Byam Martin & 2 & 2 & 2 & 1 \\
\hline Coronation & 3 & 3 & 3 & 3 \\
\hline Hidden & 2 & 2 & 2 & 2 \\
\hline Jungulu & 2 & 2 & 2 & 3 \\
\hline Katers & 2 & 2 & 2 & 1 \\
\hline Kingfisher & 2 & 3 & 2 & 2 \\
\hline Lachlan & 2 & 2 & 2 & 3 \\
\hline Long & 2 & 2 & 2 & 2 \\
\hline Mary & 2 & 1 & 1 & 1 \\
\hline Middle Osborn & 3 & 4 & 3 & 1 \\
\hline NW Molema & 1 & 1 & 1 & 2 \\
\hline Sir Graham Moore & 2 & 2 & 2 & 1 \\
\hline St Andrew & 4 & 2 & 3 & 1 \\
\hline Storr & 3 & 1 & 2 & 2 \\
\hline Sunday & 4 & 3 & 2 & 3 \\
\hline South West Osborn & 3 & 4 & 4 & 3 \\
\hline Un-named & 1 & 1 & 1 & 1 \\
\hline Uwins & 2 & 2 & 3 & 2 \\
\hline Wargul Wargul & 3 & 1 & 1 & 1 \\
\hline Wulalam & 2 & 1 & 1 & 2 \\
\hline
\end{tabular}

